\title{
Founders and Board Structure: Evidence from UK IPO Firms
}

(Accepted version of manuscript by International Review of Financial Analysis on 11 December 2017)

Chloe Yu-Hsuan Wu $\mathrm{W}^{\mathrm{a}}$, Hwa-Hsien $\mathrm{Hsu}^{\mathrm{b}, *}$

${ }^{a}$ Hull University Business School, University of Hull, Hull HU6 7RX, United Kingdom

${ }^{\circ}$ Durham University Business School, Durham University, Durham DH1 3LB, United Kingdom

\section{Abstract}

This study investigates whether a company's founders affect the combination of executive, grey and independent directors on its board at the time of initial public offering (IPO) in the UK. Particularly, we analyse how venture capitalists are associated with board structure in founder-managed and non-founder-managed firms. We find that UK IPO firms managed by founders tend to have more executive directors. Further, they are more likely to stack non-executive directors with more independent directors relative to grey directors. Venture capital ownership is not significantly associated with board structure at the IPO stage. However, further evidence suggests that venture capital ownership is negatively related to the percentage of executive directors and positively related to the percentage of grey directors in the founder-managed firms.

\section{Keywords: Corporate governance; Founders; Board structure; Venture capitalists; IPO}

\footnotetext{
* Corresponding Author: at Durham University Business School, Durham University, Mill Hill Lane, Durham, DH1 3LB, UK. Tel: +44 (0)1913340472

Email address: hwa-hsien.hsu@durham.ac.uk (H. Hsu), y.wu@hull.ac.uk (C.Y.Wu).
} 


\section{Introduction}

Firms dominated by founders represent a unique organisational structure and governance regime (Anderson \& Reeb, 2003). The existing studies primarily focus on the association between founders and firm performance in the context of established firms (e.g., Adams et al., 2009; Fahlenbrach, 2009). While the presence of founders is a common feature at the time of initial public offering (IPO), the literature on how they affect organisational arrangement at this stage is scarce (Certo et al., 2009; Gao \& Jain, 2011). Recent studies have stated that a board is structured as a response to its firm's governance regime, and they call for a better understanding of the determinants of board structure and the forces that drive its development (Harris \& Raviv, 2008; Raheja, 2005). This paper adds to the literature and investigates how founders affect board structure at the IPO in the UK. Additionally, although there is significant research on founders and institutional shareholders, there is limited research on the nexus between them. This study highlights different agency environments in founder-managed and non-founder-managed firms (e.g., Adams et al., 2009; Cable \& Shane, 1997), and it examines how venture capitalists, as powerful outside shareholders, are associated with board structure in the presence or absence of founder managers in IPO firms.

Board structure affects its functionality, and the composition of a board usually reflects the desires of various parties interested in a firm (Adams et al., 2010). Firms often establish a formal board for the first time at the IPO (Wang \& Song, 2016). The role of the board revolves around two contrasting functions (Baker \& Gompers, 2003): (1) an IPO firm may need a board that can effectively play strategic and advisory roles for enhancing its growth and responding to external competition during the IPO stage; (2) the 
IPO is the first time that a private firm raises equity from dispersed shareholders, and from the agency perspective, the increased dispersion of ownership may intensify agency conflict and thus increase the demand for effective monitoring from the board. It is argued that the way in which a board is structured to satisfy its multiple functional roles is dependent on its firm's governance regime (Harris \& Raviv, 2008). The existing powerful insiders or shareholders in a firm undergoing IPO may have a strong incentive to exercise their influence to ensure that the prevalent functionality from the board, as determined by the board structure, can enhance or preserve their interests (Gao \& Jain, 2012).

Founders are the longest-tenured members in a firm and play a critical role in directing decisions at the time of the IPO (Gao \& Jain, 2011; Wang \& Song, 2016). They usually have substantial share ownership, as well as psychological ownership, and hold important management positions (Gómez-Mejía et al., 2014). They therefore have substantial interests and controlling power. As noted above, an IPO is commonly accompanied by an increased dispersion of shareholding. The changes in ownership structure may potentially threaten the interests of the existing owners (Baker \& Gompers, 2003). This may motivate founders to use their influence to establish a board that is optimal for their best interests, minimising any costs they incur as a result of the changes of ownership structure and other governance characteristics. While there is no agreement on what constitutes an optimal configuration of directors, we argue that an IPO firm's board composition is influenced by the interests of its founders, because the board will be structured to substitute or complement the corporate governance functions played by them. 
Because board structure is associated with the distribution of power in a firm, it is usually an outcome of bargaining between dominant insiders and outside investors. Prior literature has suggested that an IPO firm's board will be framed to reflect concerns and interests of influential external shareholders such as venture capitalists, because those shareholders have a significant voice in the appointment of board members (e.g., Baker \& Gompers, 2003). The provision of venture capital is often critical to the success of IPO firms. Operationally, venture capitalists' relationship with entrepreneurs usually goes beyond the simple provision of finance. They usually exhibit more active involvement in various corporate activities in the firms, such as management oversight and strategy development, to safeguard their investment (Kaplan \& Strömberg, 2004). However, founders and venture capitalists are likely to have different objectives and interests in a business (Higashide \& Birley, 2002). Such differences may result in principal-principal agency conflicts (Cable \& Shane, 1997; Zou et al., 2016), thus motivating venture capitalists to protect their interests through their negotiation power over corporate governance arrangements (Kaplan \& Strömberg, 2004). We therefore argue that venture capitalists' attitude toward board arrangements is dependent on the presence/absence of founder managers. While the overriding governance objective of a firm may be inclined towards the preference of its founders, such an objective may deviate in the presence of greater venture capital ownership.

By examining UK non-financial companies that went public on the main market of the London Stock Exchange between 1998 and 2013, we find that the IPO firms managed by founders are more likely to have a greater percentage of executive directors on their boards. In addition, the founder-managed IPO firms tend to stack their non-executive 
directors (NEDs) with more independent directors relative to non-independent directors (also known as grey directors). ${ }^{1}$ Venture capital ownership is not significantly related to the percentages of executive, grey and independent directors, but further evidence suggests that founder-managed IPO firms are more likely to have more grey directors and fewer executive directors in the presence of greater venture capital ownership.

This paper seeks to add to the existing literature in a number of ways. First, as Linck, Netter and Yang (2008) note, relatively few studies have researched the determinants of board structure. It has been argued that founder managers differ from non-founder managers in terms of their interests, power, incentives and knowledge (Gao \& Jain, 2011). As discussed above, the study’s focus on the impact of founders on board structure has so far attracted little attention in prior literature. Similarly, there is limited knowledge about how venture capitalists react to different internal governance regimes. This paper highlights the potential principal-principal agency conflicts between founders and venture capitalists, and investigates how venture capital ownership is associated with board structure in the presence or absence of founder managers. This study thus addresses significant gaps in the literature on determinants of board structure.

Second, the prevalent functional role for a board is impacted by its structure (Harris \& Raviv, 2008). Some recent studies have conceptually or empirically examined the effectiveness of executive, grey and independent directors in fulfilling different board tasks (Baysinger \& Hoskisson, 1990; Borokhovich et al., 2014; Hsu \& Wu, 2014), ${ }^{2}$ but little is known about when those specific types of directors will be chosen. This research

\footnotetext{
1 The definition used to classify independent non-executive directors and non-independent non-executive directors (grey directors) will be further discussed in Section 3.2.

${ }^{2}$ Section 2.1 provides further discussions in respect of the features of executive, grey and independent directors.
} 
gives equal consideration to the features of those different types of directors and highlights the influences of founders and venture capitalists on the combination of those directors.

Third, a further contribution of this study lies in its emphasis on the UK setting. While there has been little research on the determinants of board structure, and previous studies have primarily focused on US firms (e.g., Baker \& Gompers, 2003; Boone et al., 2007; Linck et al., 2008), the UK context provides several distinctive features and potentially offers new insights into the determinants of board structure at the IPO stage. Prior studies have documented that founders own around 31\% of shares in their founding firms in the UK (Chahine et al., 2011), which is higher than the $22 \%$ for their US counterparts (Gao \& Jain, 2011; He, 2008). In addition, venture capitalists have around $3 \%$ of the ownership of IPO firms in the UK (Filatotchev, 2006), which is significantly lower than the $23.6 \%$ in the US (Florin, 2005). It appears that founders' ownership is significantly higher than that held by venture capitalists in the founder-managed IPO firms in the UK.

Furthermore, NEDs in the UK firms, compared to their US counterparts, may be arguably less effective in monitoring managerial conduct (Guest, 2008). It has been suggested that NEDs face relatively lower litigation risk in the UK because lawsuits against them are very rare (Franks et al., 2001). Moreover, the compensation for NEDs is relatively low in the UK (Cosh \& Hughes, 1987; Mallin et al., 2015). These factors will affect NEDs' incentives to contribute their time and efforts to their duties.

As for the regulatory environment, UK firms have more flexibility than US firms to determine their board structure, since compliance with the UK corporate governance code 
is on a 'comply or explain' basis (UK Corporate Governance Code, 2014). Therefore, IPO firms in the UK face less strict ongoing corporate governance regulation after flotation, allowing them more freedom to decide their preferred board structure. Such a governance environment provides a relatively clear setting for research on how an IPO firm's board structure is determined. Collectively, the above-mentioned governance and regulatory characteristics in the UK may affect the views and propensities of founders and venture capitalists in the process of selecting board members. Therefore, the UK provides an important and interesting setting to investigate corporate governance issues.

This paper is organised into five parts. Following the introduction, we review the extant literature and develop our hypotheses. We then describe the sample selection procedure and research design. This is followed by the results and discussion. The final section draws conclusions.

\section{Hypotheses Development}

\subsection{Board structure at IPO}

The board of directors is ultimately responsible for directing a firm's decision-making. Each director plays different roles to fulfil various functions regarding monitoring, strategy formulation, advising and resource acquisition (Fama \& Jensen, 1983). Board structure is therefore crucial to firm performance. It has been suggested that a combination of executive, independent and grey directors are appointed to ensure a board's success in managing its multiple functions (Baysinger \& Butler, 1985).

Executive, independent and grey directors are different in nature. A firm's characteristics affect the combination of those different types of directors on its board in 
order to fulfil the firm's relative need for various board functions (Coles et al., 2008). Operationally, executive directors are involved in day-to-day management functions in a firm. They have good stewardship and work closely with the management team (Davis et al., 1997). Their firm-specific knowledge enables them to play an effective advisory role for decision-making (Fama \& Jensen, 1983). Nevertheless, it has been suggested that an increased number of executive directors on a board may lead to managerial entrenchment and intensify the agency conflict between management and external investors (Raheja, 2005).

In contrast, both independent and grey directors are NEDs with no day-to-day executive duties. However, they differ from each other in terms of their ties with firms beyond their non-executive positions. While grey directors have significant economic or personal affiliations with a firm, independent directors are strict outsiders. ${ }^{3}$ It is argued that the presence or absence of such affiliations affects those directors' capacities and incentives in performing their monitoring, advisory and resource-dependence roles (Adams, 2009; Baysinger \& Hoskisson, 1990; Borokhovich et al., 2014; Hsu \& Wu, 2014).

Operationally, independent directors are expected to be tough monitors (Adams \& Ferreira, 2007). From the agency perspective, independent directors are more likely to objectively challenge managerial decisions because they are relatively distant from the firm and management (Fama \& Jensen, 1983). In addition, they are motivated to oversee top management in order to protect their reputation in the external labour market (Fama, 1980). In contrast, it is argued that independent directors do not possess sufficient

\footnotetext{
3 This study adopts the criteria set by the UK Corporate Governance Code (2014) to distinguish independent and grey directors. See footnote 6 for the precise criteria.
} 
firm-specific information, nor do they understand the business thoroughly, because they generally serve on a part-time basis (Raheja, 2005). Further, their strict monitoring duty is likely to discourage executive directors from sharing privileged information with them in order to avoid intense scrutiny (Adams \& Ferreira, 2007). This may lead to independent directors relying on their general knowledge rather than firm-specific knowledge in performing monitoring roles, thus impairing their effectiveness. As noted previously, it is argued that independent directors in the UK, compared to the US, receive lower compensation and face lower litigation risk (Cosh \& Hughes, 1987; Franks et al., 2001; Mallin et al., 2015), and they may therefore be less incentivised to contribute their efforts and time to their duties thus playing a weaker monitoring role (e.g., Guest, 2008).

From the agency perspective, grey directors' affiliations with a firm may reduce their incentives to act against management, thus placing them in a compromised position (Fama \& Jensen, 1983). However, the presence of personal and economic ties could enable grey directors to access critical firm-specific information and develop a better collaborative working relationship with management. Such relationships can facilitate information flow among board members, thus increasing valuable interactions for decision-making (Borokhovich et al., 2014). In addition, grey directors' interests in the firm provide them with greater incentives than independent directors to contribute their effort and time to the firm they serve (Baysinger \& Butler, 1985). While independent directors are generally regarded as strict monitors by corporate governance reformers, some argue that grey directors are more confident and powerful and more likely to challenge management when necessary (Borokhovich et al., 2014; Buchanan II, 1974). Grey directors possess firm-specific information, experiences and skills acquired through 
their affiliations with the firm, which can be of benefit to their monitoring functions, particularly when they serve a firm with greater information asymmetry (Borokhovich et al., 2014; Buchanan II, 1974). In addition, their incentive to contribute to oversight activities may be stronger than that of independent directors because they are confronted with an increased risk to their financial and personal interests when a firm faces greater uncertainty and challenges (Borokhovich et al., 2014). The presence of such interests may even give grey directors motivation to monitor management constructively, thereby securing their interests in the firm. Therefore, grey directors act in the combined role of executive director when providing advice and resources and independent director when playing the monitoring role (Borokhovich et al., 2014; Hsu \& Wu, 2014)

As noted above, IPO firms face the challenges of increasing agency conflicts and seeking advice and resources to facilitate their growth. The composition of the board is therefore critical to how IPO firms respond to these two challenges. This provides powerful managers or investors, such as founders and venture capitalists, with incentives to exercise their influence to establish a board that maximises and safeguards their own interests as well as securing their authority. Board composition at the time of an IPO may therefore be determined by the choices of those managers and investors and made to serve their interests, or be a reflection of an organisation's design of corporate governance in response to the potential agency problem arising from the presence of entrenched insiders (Hermalin \& Weisbach, 1998).

\subsection{Founders and board structure}

Founders play a central role from the time a firm is established. They typically hold an important managerial position such as that of CEO or a position on the board, and they 
retain a large proportion of the firm's ownership. Founders are the longest-tenured members in the firm. Their human capital is valuable to firms due to their innovative nature and firm-specific knowledge and experience. Founders are therefore in a better position to formulate effective strategies (Certo et al., 2001). These features enable founders to have significant power and capability to influence a firm's policies and organisational structure (He, 2008; Nelson, 2003).

Prior studies also provide arguments regarding the presence of founders in an organisation (Gao \& Jain, 2011). From the agency perspective, founders' significant controlling power and ownership may enable them to be entrenched and to act in their own interests (La Porta et al., 1999). The increasingly dispersed ownership structure at the IPO stage may increase the divergence of interests between founders and shareholders and consequently give founders an incentive and opportunity to pursue their private interests at the expense of minority shareholders. Further, such changes in ownership may also motivate founders to retain their authority and legitimacy in the firms by taking advantage of their bargaining position (Hermalin \& Weisbach, 1998).

As board structure is associated with the distribution of power in a firm, dominant insiders such as founders usually seek to minimise effective monitoring from the board of directors (Anderson \& Reeb, 2004; Shleifer \& Vishny, 1986). They are inclined to choose directors who are more likely to support their decisions and less likely to challenge their power (Jaggi \& Leung, 2007; Shivdasani \& Yermack, 1999). Consequently, founders are more likely to prefer more executive directors in order to centralise their control and avoid challenges and oversight from NEDs. We therefore formulate the following hypothesis: 
Hypothesis 1a: IPO firms managed by founders or with higher founder ownership are more likely to have a higher proportion of executive directors on their boards.

There is greater information asymmetry in IPO firms. Founders, as powerful insiders, are likely to exploit their superior access to information at the expense of other shareholders in order to maximise their interests and minimise their costs incurred by the changes of ownership structure (Gao \& Jain, 2012). They are typically reluctant to offer critical information to outsiders to avoid informed monitoring (Harris \& Raviv, 2008; Jensen, 1993). As discussed above, the quality of information available to independent directors is always at insiders' discretion (e.g., Chancharat et al., 2012; Duchin et al., 2010; Harris \& Raviv, 2008). The capability of independent directors to oversee management may therefore be confined by their lack of firm-specific knowledge in firms dominated by founders. Grey directors, compared to independent directors, may have better informational advantage to effectively challenge management in order to protect their own interests (Borokhovich et al., 2014; Hsu \& Wu 2014). We therefore argue that founders are more likely to prefer more independent directors relative to grey directors in order to safeguard their authority and avoid intensive oversight from grey directors. Consequently, we formulate the following hypothesis:

Hypothesis 1b: IPO firms managed by founders or with greater founder ownership are more (less) likely to stack their NEDs with independent (grey) directors on their boards.

\subsection{Venture capitalists and board structure}

Venture capitalists have influential power at the time of an IPO. Investment by 
venture capitalists is growing in European countries (Chahine et al., 2007). It is documented that the UK is more likely to attract investment by venture capitalists among these countries because this capital market is larger, has higher liquidity and has better investor protection (Groh et al., 2010). ${ }^{4}$ Venture capitalists are important sources of capital for entrepreneurial firms and play multiple roles beyond the funds they invest to assist an IPO firm in responding to the competitive environment. Venture capitalists view an IPO as an attractive opportunity to exit and realise their profits. In order to maximise their returns when exiting portfolio firms, venture capitalists actively offer support to ventures in different aspects, such as management mentoring, strategy development and resource acquisition.

Since board structure is critical to post-IPO performance and the likelihood of IPO survival (Chancharat et al., 2012; Kroll et al., 2007), venture capitalists have strong incentives to be involved in human capital arrangements and to influence the development of the top management team at the IPO stage in order to ensure the best outcomes for their investment (Hellmann \& Puri, 2002). Additionally, they have greater incentives to monitor and constrain managerial discretions through their negotiating power in order to safeguard their profits (Baker \& Gompers, 2003; Boone et al., 2007; Shekhar \& Stapledon, 2007). As discussed above, a new IPO firm has increased demand for both monitoring and advisory functions from its board in order to deal with the increased competition and challenges in the market. We therefore argue that venture capitalists do not prefer insider-dominated boards, leaning more towards boards with external inputs that offer effective monitoring and/or advice. This study therefore

\footnotetext{
${ }^{4}$ Alhadab et al. (2015) statistically document that $22.1 \%$ of IPOs were venture-backed firms in the UK during the period from 1998 to 2008.
} 
formulates the following hypothesis:

Hypothesis 2: There is a negative (positive) relationship between venture capital ownership and the proportion of executive directors (NEDs) on the boards of IPO firms.

\subsection{Venture capitalists and board structure in founder-managed and non-founder-managed IPO firms}

As discussed previously, founder-managed firms have a unique governance regime, as founder managers differ from non-founder managers in terms of their managerial incentives, interests, power and knowledge (Gao \& Jain, 2011). Although founders have good firm-specific knowledge, they may not possess the expertise and experience required to manage the complexity of publicly traded companies (e.g., Adams et al., 2009; Wasserman, 2006). Venture capitalists are equipped with the skills and resources that could compensate for this shortcoming (Certo et al., 2001; Daily \& Dalton, 1992). Their knowledge and access to networks in the market increase the credibility of a firm and decrease the costs incurred throughout the process of an IPO. IPO firms backed by venture capital tend to receive a positive response from investors, as the involvement of venture capitalists signals certification of firm value (Busaba et al., 2001; Busaba, 2006; Dunbar \& Foerster, 2008). Venture capitalists are therefore more likely to be invited by founders to invest in a venture firm with a high uncertainty of future profitability, because founders expect that venture capitalists' investment and involvement can add value to the entrepreneurial firm as well as helping to diversify their risk incurred in the process of going public (Amit et al., 1990). 
However, founders are incentivised to enhance or preserve their domination in order to protect their own economic and non-economic wealth associated with their founding firms (Gómez-Mejía et al., 2014). They usually view venture capitalists as strict monitors. While venture capitalists need to utilise firm-specific information to enhance their functional roles, the availability of such information is always at the discretion of the founders, who are usually reluctant to share critical insider information with venture capitalists (Kaplan \& Strömberg, 2004). To maintain their inherent legitimacy and control, founder managers may attempt to withhold firm-specific information in order to avoid informed challenges posed by venture capitalists, even if this action may negatively impact firm value (Gómez-Mejía et al., 2014; Gedajlovic et al., 2004; Le et al., 2013). Such entrenchment behaviour often puts founders at odds with venture capitalists, and may be a threat to the interests of venture capitalists.

Operationally, venture capitalists face significant investment risk because the failure rate of venture-backed firms is high (Zacharakis \& Meyer, 2000). The principal-principal agency conflict associated with the asymmetric power and divergent interests between venture capitalists and entrepreneurs is a risk to the potential success of these firms, and it consequently poses a significant threat to the financial return for venture capitalists (Cable \& Shane, 1997; Zacharakis \& Meyer, 2000). Therefore, venture capitalists have strong incentives to exercise power over the firms they invest in and attempt to sway the activities of these firms and their entrepreneurs. They will act to ensure that an effective corporate governance mechanism is in place to safeguard their investment.

Prior literature suggests that venture capitalists will use their bargaining power to negotiate a preferred board structure when an IPO firm is managed by founders 
(Anderson \& Reeb, 2004; Kaplan \& Strömberg, 2003, 2004; Lerner, 1995). As discussed above, grey directors, compared to independent directors, have better informational advantages and economic incentives to constructively monitor the process and strategy of the firm. Their affiliations with the firm will also enable them to act like inside directors on decision-making (Borokhovich et al., 2014; Buchanan II, 1974). We therefore argue that venture capitalists would strategically favour a board composed of more grey directors in founder-managed IPO firms. This study therefore formulates the following hypothesis:

Hypothesis 3: The positive relationship between venture capital ownership and the proportion of grey directors is more pronounced in founder-managed IPO firms.

\section{Research Methods}

\subsection{Sample selection}

This study examines the influence of founders and venture capitalists on the composition of board structure at an IPO stage. The empirical tests examine UK non-financial firms that went public on the main market of the London Stock Exchange (LSE) between 1998 and 2013. ${ }^{5,6}$ An initial sample of 217 firms is drawn from the LSE New Issues files. Corporate governance and accounting data of each sample firm are

\footnotetext{
${ }^{5}$ The Alternative Investment Market (AIM) on the London Stock Exchange may provide an alternative setting for our analysis. However, the AIM has lower listing and disclosure requirements than the main market (Espenlaub et al., 2012). Farag et al. (2014) have reported that the level of corporate governance information disclosed in IPO prospectuses varies among the firms undergoing an IPO in the AIM. This issue may potentially restrict the availability and consistency of such information required for our analysis. Firms undergoing an IPO in the main market face more stringent listing and disclosure requirements, thus providing more details about corporate governance information in their IPO prospectuses. Our analysis therefore emphasises the firms on the main market.

6 This study excludes financial companies due to the fact that they are often subject to special rules and recommendations and their financial structure is distinct from other companies.
} 
manually collected from IPO prospectuses. Firms without a complete set of corporate governance and financial data are excluded from our initial sample. Data of venture capital-backed IPO firms is identified based on the British Venture Capital Association (BVCA) Directory, Venture Capital Report Guide to Venture Capital in the UK, European Venture Capital Association (EVCA) online directory and Pratt's Guide to Venture Capital Sources. The final sample is composed of 210 IPOs.

\subsection{Regression model and specification}

To investigate our hypotheses, OLS regression is employed. The general models are developed as follows:

$E D, I N E D, G R E Y$ or INED_NED $=\beta_{0}+\beta_{1} F D R \_M G D_{i}+\beta_{2} F D R \_O W N_{i}+\beta_{3} V C \_O W N_{i}$ $+\beta_{4} C E O \_A G E_{i}+\beta_{5} L E V_{i}+\beta_{6} L n C O M \_S I Z_{i}+\beta_{7} L n C O M \_A G E_{i}+\beta_{8} U N D E R W R I T E R_{i}+$ $\beta_{9} F C F_{i}+e_{i}$

where

$E D \quad=$ the percentage of executive directors on board;

INED = the percentage of independent NEDs on board;

GREY = the percentage of non-independent (grey) NEDs on board;

$I N D \_N E D \quad=$ the ratio of independent directors to total NEDs;

FDR_MGD = the presence of a founder who holds the position of CEO or chairman, coded 1 if the positions of CEO and/or chairman are held by the founder, or 0 otherwise;

FDR_OWN = the percentage of the company shares owned by founders;

VC_OWN $=$ the percentage of the company shares owned by venture 
capitalists;

CEO_AGE = the age of CEOs;

$L E V \quad$ = the ratio of total debts to total assets;

LnCOM_SIZ = natural log of total assets (proxy for firm size);

LnCOM_AGE = natural log of company age;

UNDERWRITER = underwriter reputation measured by the market share of the underwriter across the sample period;

FCF $\quad=$ the ratio of free cash flow to total assets.

For dependent variables, we measure board structure by the percentages of executive directors (ED), independent NEDs (INED) and grey directors (GREY) on the main board. We use the independent/non-independent NED distinction set out in the UK Corporate Governance Code (2014, para. B.1.1.) to classify independent and grey directors. ${ }^{7}$ Relying on this approach, an NED is coded as a grey director if this person has economic or personal affiliations with the firm, as set out in the Code. The ratio of independent NEDs to total NEDs (INED_NED) is used to measure the composition of NEDs on boards.

For independent variables, we employ the presence of founders who hold the position of CEO or chairman of the board (FDR_MGD) to classify founder-managed and non-founder-managed firms (Villalonga \& Amit, 2006). The percentage of a firm’s shares controlled by its founders is used to measure the founders' ownership (FDR_OWN).

\footnotetext{
${ }^{7}$ The UK Corporate Governance Code (2014) sets precise criteria for independence on the basis of whether a director: (a) has been an employee of the company or group within the last five years; (b) has or had in the last three years a material business relationship with the company; (c) has received additional remuneration such as a performance-related payment and pension from the company apart from a director's fee; (d) has close family ties with the company's other directors, advisors, or senior employees; (e) holds cross-directorships; (f) represents a significant shareholder; or (g) has served on the board for more than nine years. This approach is also employed by Hsu and Wu (2014).
} 
Those two variables are adopted to capture the influence of founders on a company. The percentage of a firm's shares owned by venture capitalists (VC_OWN) is used to measure the interest and influence of the venture capitalist(s) in that company.

The control variables are drawn from prior studies. This research employs five groups of control variables. First, CEO age (CEO_AGE) is controlled for a CEO's personal characteristics relating to the sense of job security, risk propensity and commitment to a firm (e.g., Buchholtz \& Ribbens, 1994; Hambrick \& Mason, 1984). It is thus expected that CEO age has an impact on an organisation's governance arrangement for its boards.

Second, leverage (LEV) may contribute to managerial entrenchment. Managers may increase leverage to reinforce their control and reduce the discipline of the market for corporate control (e.g., Harris \& Raviv, 1988; Stulz, 1988). In contrast, the use of debts may restrict managers' control over free cash flow and increase the scrutiny from debtholders (Fama, 1980; Jensen, 1986). Leverage may therefore affect the demand for monitoring from the board.

Third, company size (LnCOM_SIZ) and company age (LnCOM_AGE) are used to control for the complexity and scope of a firm's operation (e.g., Linck et al., 2008). The effect of company size and company age on board arrangement is ambiguous, but both are positively related to board independence because the benefit of monitoring increases. In contrast, the demand for board monitoring may be greater in small and young firms because those firms typically have higher risk.

Fourth, the reputation of the underwriter (UNDERWRITER) is controlled. It is suggested that underwriters play a critical role in certifying the quality of the IPOs during 
the floatation (Carter \& Manaster, 1990; Migliorati \& Vismara, 2014). Underwriters with higher market share have higher incentives to maintain their reputation in the capital market. Therefore, they are more likely to use their bargaining power to affect board composition to ensure the success of the floatation (Boone et al., 2007).

Finally, we use the ratio of free cash flow ${ }^{\mathbf{8}}$ to total assets (FCF) to capture the agency problem of the firms. It is argued that managers in firms with higher free cash flow are more likely to be entrenched (Jensen, 1986). The presence of higher managerial entrenchment increases the propensity of managers to exercise their influence to reduce board oversight in such firms, thus increasing the number of executive directors (Coles et al., 2008).

\section{Results}

\subsection{Descriptive statistics and univariate analysis}

Table 1 shows the descriptive statistics for all the sample firms. In addition, it displays the statistics for the founder-managed IPOs compared to the non-founder-managed IPOs and reports the results of the t-test and the Wilcoxon rank sum test for each variable. Of the sample firms, $46 \%$ are founder-managed IPOs and 54\% are non-founder-managed IPOs (FDR_MGD). On average, 46.41\%, 36.85\% and 16.71\% of members on a new IPO's board are executive directors $(E D)$, independent directors (INED) and grey directors (GREY), respectively. The mean percentages of executive directors for the founder-managed and non-founder-managed firms are $51.69 \%$ and 42.81\%, respectively, and this difference is statistically significant $(\mathrm{p}<0.01)$. It appears

\footnotetext{
8 Free cash flow is equal to operation earnings plus depreciation charge less capital expenditure.
} 
that the boards of the founder-managed firms are generally controlled by executive directors. The findings support Hypothesis 1a, which states that founder-managed firms are likely to have a greater percentage of executive directors on their boards.

The average percentages of grey directors (GREY) for the founder-managed and non-founder-managed firms are $12.47 \%$ and $20.28 \%$, respectively, and this difference is statistically significant $(\mathrm{p}<0.01)$, indicating that more grey directors are employed by the non-founder-managed firms than the founder-managed firms. However, the mean percentages of independent directors (INED) for the founder-managed and non-founder-managed firms are $36.84 \%$ and $36.91 \%$, respectively, but this difference is not significant. Compared to the non-founder-managed firms, the founder-managed firms have a significantly higher ratio of independent directors to total NEDs (INED_NED) (p $<0.01$ ). This result appears to indicate that, with regard to the composition of NEDs, founder-managed IPOs are more likely to increase the representation of independent directors relative to grey directors on their boards.

On average, $14.07 \%$ and $4.86 \%{ }^{9}$ of the shares are owned by founders (FDR_OWN) and venture capitalists $\left(V C_{-} O W N\right)^{\mathbf{1 0}}$, respectively, at the IPO stage. The average ownership of shares by founders (FDR_OWN) is $27.83 \%$ and $2.49 \%$ for the founder-managed and non-founder-managed firms, respectively, and this difference is statistically significant $(\mathrm{p}<0.01)$. However, there is no significant difference in the percentage of shares owned by venture capitalists (VC_OWN) between the founder-managed and non-founder-managed firms. The venture capitalists own an

\footnotetext{
${ }^{9}$ This finding is higher than the $2.93 \%$ reported by Filatotchev (2006) in terms of IPO firms in the main market and the AIM.

${ }^{10}$ Of our sample firms, $27.62 \%$ are backed by venture capitalists.
} 
average of $4.28 \%{ }^{11}$ and $5.35 \%$ of the shares in the founder-managed and non-founder-managed IPOs, respectively.

As for the control variables, the average age of CEOs (CEO_AGE) is 47.27. The CEOs' ages for the non-founder-managed IPOs are significantly higher than those for their founder-managed counterparts $(\mathrm{p}<0.01)$. Compared to the non-founder-managed firms, the founder-managed firms have lower leverage ratio $(L E V)(\mathrm{p}<0.01)$ and smaller company size $($ LnCOM_SIZ) $(\mathrm{p}<0.01)$. On average, the founder-managed firms are younger than the non-founder-managed firms $\left(C O M \_A G E\right)(\mathrm{p}<0.01)$. In addition, the non-founder-managed firms are inclined to nominate a more reputable underwriter (UNDERWRITER) (Wilcoxon test: $\mathrm{p}<0.05$ ). The founder-managed firms have a significantly lower ratio of free cash flow to total assets $(F C F)$ than their non-founder-managed counterparts (t-test: $\mathrm{p}<0.05$ ), suggesting a potentially higher agency problem in the non-founder-managed firms.

[Insert Table 1 Here]

\subsection{Results and discussions of the regression analysis}

Table 2 presents correlations between the variables adopted in regression analysis. Multicollinearity in regression analysis may be considered harmful when correlations

\footnotetext{
11 This is consistent with the findings of previous studies by Chahine et al. $(2007,2011)$ that report $4.28 \%$ and $4.2 \%$ of ownership being held by venture capitalists, respectively, in the founder-involved IPOs. 
exceed 0.7 (Tabachnick \& Fidell, 2007). The correlations between independent variables employed in each regression model in this research are below 0.43 . In addition, the variance inflation factors (VIFs) of all the cases presented in Tables $\mathbf{3}$ to 9 are below 2.0, which is lower than the threshold value of 10 (Tabachnick \& Fidell, 2007). The results of these examinations suggest that multicollinearity is not a major problem in our regression models.

[Insert Table 2 Here]

Table 3 shows the results of the regression models used to investigate the association between founders, venture capital ownership and the percentage of executive directors on boards $(E D)$ at the IPO stage. The results suggest that the IPO firms managed by founders (FDR_MGD) are more likely to have more executive directors on their boards (Model 1, $\mathrm{p}<0.05$ ). The percentage of executive directors on a board is positively related to the proportion of the company shares owned by founders (FDR_OWN) (Model 2, $\mathrm{p}<0.01$ ). These results are consistent with Hypothesis 1a, which states that executive directors are more likely to be nominated in the founder-managed firms, because founders are inclined to have more executive directors on their boards in order to strengthen their authority for effective decision-making and to protect their own interests (Hermalin \& Weisbach, 1998; Sundaramurthy \& Lewis, 2006). 
[Insert Table 3 Here]

Table 4 presents the results for the associations between founders, venture capital ownership and the percentages of independent directors and grey directors. As indicated above, both independent directors and grey directors are NEDs, but they may play different corporate governance roles in a firm. The results show that founder-managed firms (FDR_MGD) tend to have a higher percentage of independent directors (INED) (Model 1, p < 0.05) while having a lower percentage of grey directors (GREY) (Model 2, $\mathrm{p}<0.05)$. Similarly, an IPO firm with higher founder ownership $\left(F D R \_O W N\right)$ is more likely to have more independent directors (INED) (Model 4, p < 0.10) and fewer grey directors (GREY) (Model 5, p < 0.01). Models 3 and 6 in Table 4 further examine whether the weight of independent directors relative to grey directors on a board is greater for founder-managed firms and is associated with founder ownership. The findings demonstrate that the ratio of independent directors to total NEDs (INED_NED) is higher in founder-managed firms $\left(F D R \_M G D\right)$ (Model 3, $\mathrm{p}<0.01$ ) and is positively related to founder ownership $\left(F D R \_O W N\right)$ (Model 6, p < 0.01). The findings suggest that an IPO firm with influential founders is more likely to stack its NEDs with more independent directors, instead of grey directors, which is consistent with Hypothesis $1 \mathrm{~b}$. Such findings may imply that founders may be inclined to nominate fewer grey directors on their boards in order to avoid effective monitoring from those directors, because grey directors, as noted previously, are argued to be better informed and have greater 
incentives than independent directors to carry out oversight activities to protect their interests when a firm faces greater uncertainty and challenges such as those arising when undergoing an IPO (Baysinger \& Butler, 1985; Borokhovich et al., 2014).

With regard to the relationship between venture capital ownership and board structure, Table 3 shows that the percentage of executive directors $(E D)$ is not significantly related to venture capital ownership (VC_OWN), which does not support Hypothesis 2. Furthermore, Table 4 demonstrates that venture capital ownership $\left(V C \_O W N\right)$ is not significantly associated with the percentages of independent directors (INED) and grey directors (GREY) either. The findings are different from the existing studies grounded in the US, which show that firms backed by venture capital have more independent directors and fewer executive directors (Baker \& Gompers, 2003; Boone et al., 2007).

[Insert Table 4 Here]

Table 5 explores the effect of venture capital on the choice of board members in the founder-managed and non-founder-managed IPO firms. With regard to the founder-managed firms, Model 1 shows a negative association between the percentage of executive directors $(E D)$ and venture capital ownership $\left(V C_{-} O W N\right)(\mathrm{p}<0.01)$. No significant association is found between the percentage of independent directors (INED) and venture capital ownership (VC_OWN) (Model 2), while the percentage of grey 
directors (GREY) has a significantly positive association with venture capital ownership (Model 3, $\mathrm{p}<0.05$ ). Model 4 further shows that there is a negative relationship between the ratio of independent directors to the total number of NEDs (INED_NED) and the venture capital ownership $\left(V C \_O W N\right)$ in the founder-managed firms $(\mathrm{p}<0.1)$, suggesting that the founder-managed firms with a greater percentage of shares controlled by venture capitalists are more likely to stack their NEDs with grey directors rather than independent directors.

However, the percentages of executive directors (ED) (Model 5), independent directors (INED) (Model 6) and grey directors (GREY) (Model 7), as well as the ratio of independent directors to total NEDs (INED_NED) (Model 8), are not significantly related to venture capital ownership (VC_OWN) in the non-founder-managed firms. Overall, the findings support Hypothesis 3 and imply that venture capitalists are inclined to appoint more grey directors, who, due to their firm-specific knowledge and economic ties to a firm, may effectively mitigate the potential conflicts arising from the information asymmetry and the principal-principal agency problem between founder-managers and themselves, thus promoting their mutual collaboration in the venture-backed IPO firms.

[Insert Table 5 Here]

\subsection{Additional analysis}

We conduct additional robustness tests to ensure the validity of our findings. First, 
Shivdasani and Yermack (1999) argue that CEOs are less likely to appoint directors who would effectively monitor them. Since members of a nomination committee can make decisions on appointments of directors (UK Corporate Governance Code, 2014), we use the presence of founders on the committee as an alternative proxy to examine founders' influences on board structure. The presence of founders on a nomination committee ( $F D R \_N C$ ) is measured by a dummy variable given a value of 1 if a founder serves on the committee, or 0 otherwise. Table 6 reports that IPO firms with founders on a nomination committee (FDR_NC) are more likely to appoint more executive directors (ED) (Model 1, $\mathrm{p}<0.05$ ). In addition, firms tend to appoint more independent directors (INED) (Model 2, $\mathrm{p}<0.10$ ) and fewer grey directors $(G R E Y)$ (Model 3, $\mathrm{p}<0.05$ ) when there are founders serving on a nomination committee $\left(F D R \_N C\right)$. The presence of founders on a nomination committee (FDR_NC) is also positively related to the ratio of independent directors to total NEDs (INED_NED) (Model 4, $\mathrm{p}<0.01$ ). These results support the main findings reported in Tables $\mathbf{3}$ and $\mathbf{4}$ showing that founder-managed IPOs are inclined to appoint executive directors and stack NEDs with independent directors on their boards.

[Insert Table 6 Here]

Second, prior studies have suggested that institutional investors generally control significant shareholdings and play an active monitoring role in UK firms (Short \& Keasey, 1999). We therefore perform additional tests by replacing venture capital 
ownership with institutional ownership in the regression analysis to examine the effect of institutional investors on an IPO firm's board structure. Institutional ownership (INS_OWN) is measured by the percentage of the company shares owned by institutional shareholders. Table 7 shows that, generally, institutional ownership is not significantly associated with the percentage of executive directors (ED) (Model 1), independent directors (INED) (Model 2) and grey directors (GREY) (Model 3) on a board at the IPO stage. However, Panel A of Table 8 shows a negative relationship between the percentage of executive directors (ED) and institutional ownership (INS_OWN) in the founder-managed firms (Model 1, p < 0.05). Institutional ownership (INS_OWN) is not significantly associated with the percentage of independent directors (INED) in the IPO firms led by founders (Model 2), while the percentage of grey directors (GREY) has a significantly positive relationship with the percentage of institutional ownership (INS_OWN) in such firms (Model 3, p < 0.01). Model 4 further shows that there is a significantly negative association between the ratio of independent directors to the total number of NEDs (INED_NED) and institutional ownership (INS_OWN) in the founder-managed firms (Model 4, p < 0.05). Panel B of Table 8 further shows that the percentage of institutional ownership is not significantly associated with the percentages of executive directors (ED) (Model 1), independent directors (INED) (Model 2) and grey directors (GREY) (Model 3) in the non-founder-managed firms. Overall, these results reflect that the effect of institutional investors on board structure is consistent with that of venture capitalists presented in Tables 4 and 5.

Third, venture capitalists and business angels are two major types of private equity. Prior literature argues that, similar to venture capitalists, business angels also actively 
exercise their monitoring function over their investees (e.g., Bruton et al., 2010; Chahine et al., 2007). We therefore examine how business angel ownership affects board structure in IPO firms. We measure business angel ownership (ANGEL_OWN) by the percentage of the company shares owned by business angels. ${ }^{12}$ Table 7 reports that the shareholdings held by business angels (ANGEL_OWN) is not significantly associated with the percentages of executive directors $(E D)$ (Model 5), independent directors (INED) (Model 6) and grey directors (GREY) (Model 7). Unlike the effects of venture capital ownership reported in Table 5, Table 8 shows that business angel ownership (ANGEL_OWN) is not significantly related to the percentages of the different types of directors on a board in either founder-managed or non-founder-managed IPO firms (Panels A and B of Models 5 to 8).

[Insert Table 7 Here]

[Insert Table 8 Here]

12 Consistent with Bruton et al. (2010), we define business angels as those invested in the venture as private individuals not affiliated with founders, other board members, senior managers, or venture capitalists. 
Fourth, we adopt an alternative approach suggested by Faleye, Hoitash and Hoitash (2011) to classify NEDs. They argue that NEDs are more likely to provide effective monitoring when serving on a minimum of two out of three major board sub-committees (audit, remuneration and nomination committees), as they would contribute more time to the firm and gain better knowledge about its operation. Table 9 shows that IPO firms with founder managers $\left(F D R \_M G D\right)$ (Model 1, $\left.\mathrm{p}<0.05\right)$ and greater founder ownership $\left(F D R \_O W N\right)$ (Model 2, $\left.\mathrm{p}<0.05\right)$ are less likely to have a higher proportion of NEDs who serve on at least two oversight committees (NED_COMS). Additionally, Table 9 also reveals that there is a positive relationship between venture capital ownership (VC_OWN) and the percentage of NEDs holding membership of two or more oversight committees (NED_COMS) in the founder-managed firms (Model 3, p < 0.01). However, this relationship is not significant in the non-founder-managed firms (Model 4). The results are in line with the main findings, implying that founders are not inclined to appoint NEDs who are more capable of overseeing their activities effectively. In contrast, venture capitalists tend to appoint such NEDs in the presence of founder managers.

Finally, venture capitalists may appoint NEDs who directly represent their interests on a board. Such NEDs will be classifed as grey directors in terms of the definition discussed earlier in Section 3.2. We therefore perform additional tests to examine the effects of founder managers (FDR_MGD), founder ownership (FDR_OWN) and venture capital ownership (FDR_OWN) on the percentage of grey directors who are not related with the venture capitalists on a board (GREY_NVC) (Chahine \& Goergen, 2011). Table 9 reports that IPO firms with founder managers $\left(F D R \_M G D\right)$ (Model 5, p $<0.01$ ) and greater founder ownership $\left(F D R \_O W N\right.$ ) (Model 6, p < 0.01) are still inclined not to 
appoint such directors to a board. However, founder-managed firms with greater venture capital ownership (VC_OWN) still tend to appoint grey directors (GREY_NVC) even if these directors do not directly represent their interests (Model 7, p $<0.05$ ). Overall, these results are consistent with the main findings relating to the percentage of grey directors reported in Tables 4 and 5.

[Insert Table 9 Here]

\section{Conclusions}

Founders and venture capitalists are influential corporate participants at the IPO stage. Due to the importance of a board for various corporate functions, they have incentives to exercise their power in designing a board structure that can protect their best interests in the process of going public. This research examines how a company's founders and venture capitalists influence its board structure at the time of an IPO in the UK. Particularly, we analyse how venture capitalists are associated with board structure in founder-managed and non-founder-managed firms. In addition, this study awards equal consideration to executive, independent and grey directors, and it extends prior literature to address the determinants of those three different types of directors in the context of an IPO (Borokhovich et al., 2014; Hsu \& Wu, 2014).

The empirical results suggest that IPO firms managed by founders or with greater founder ownership are more likely to have a greater percentage of executive directors on 
their boards. In addition, founder-managed IPO firms are more likely to stack their NEDs with more independent directors relative to grey directors. In general, venture capital ownership is not significantly associated with the percentages of executive, grey and independent directors. However, further evidence suggests that founder-managed firms with greater venture capital ownership are more likely to appoint more grey directors and fewer executive directors.

The results of this study have implications for corporate governance literature and practice in relation to how influential governance participants determine board structure in firms undergoing dramatic changes and facing uncertainties. In line with the agency perspective and the conceptual argument of Harris and Raviv (2008), powerful insiders of entrepreneurial firms that simultaneously face increasing challenges for growth and intensified agency conflicts may be inclined to have a board that strengthens their authority and legitimacy for decision-making and avoids effective monitoring. The findings also demonstrate that active institutional investors may counterbalance the power of dominating insiders by exercising their influence to stack NEDs with directors who have better firm-specific information and greater incentives for monitoring duties. 


\section{References}

Adams, R. (2009). Asking directors about their dual roles. Working paper, University of Queensland.

Adams, R., Almeida, H., \& Ferreira, D. (2009). Understanding the relationship between founder-CEOs and firm performance. Journal of Empirical Finance, 16, 136-150.

Adams, R., \& Ferreira, D. (2007). A theory of friendly boards. The Journal of Finance, 62, 217-250.

Adams, R., Hermalin, B. E., \& Weisbach, M. S. (2010). The role of boards of directors in corporate governance: A conceptual framework and survey. Journal of Economic Literature, 48, 58-107.

Alhadab, M., Clacher, I., \& Keasey, K. (2015). Real and accrual earnings management and IPO failure risk. Accounting and Business Research, 45(1), 55-92.

Amit, R., Glosten, L., \& Muller, E. (1990). Entrepreneurial ability, venture investments, and risk sharing. Management Science, 36(10), 1232-1245.

Anderson, R., \& Reeb, D. (2003). Founding-family ownership and firm performance: Evidence from the S\&P 500. The Journal of Finance, 58, 1301-1328.

Anderson, R., \& Reeb, D. (2004). Board composition: Balancing family influence in S\&P 500 firms. Administrative Science Quarterly, 49(2), 209-237.

Baker, M., \& Gompers, P. A. (2003). The determinants of board structure at the initial public offering. Journal of Law and Economics, 46(2), 569-598.

Baysinger, B., \& Butler, H. (1985). Corporate governance and the board of directors: Performance effects of changes in board composition. Journal of Law, Economics, and Organization, 1, 101-124.

Baysinger, B., \& Hoskisson, R. E. (1990). The composition of board of directors and strategic control: Effects on corporate strategy. Academy of Management Review, 15(1), 72-87.

Boone, A. L., Field, L. C., Karpoff, J. M., \& Raheja, C. (2007). The determinants of corporate board size and composition: An empirical analysis. Journal of Financial Economics, 85, 66-101.

Borokhovich, K., Boulton, T., Brunarski, K., \& Harman, Y. (2014). The incentives of grey directors: Evidence from unexpected executive and board chair turnover. Journal of Corporate Finance, 28, 102-115.

Bruton, G. D., Filatotchev, I., Chahine, S., \& Wright, M. (2010). Governance, ownership structure, and performance of IPO firms: The impact of different types of private equity investors and institutional environments. Strategic Management Journal, 31, 491-509.

Buchanan II, B. (1974). Building organizational commitment: The socialization of managers in work organizations. Administrative Science Quarterly, 19(4), 533-546.

Buchholtz, A., \& Ribbens, B. A. (1994). Role of Chief Executive Officers in takeover resistance: Effects of CEO incentives and individual characteristics. Academy of Management Journal, 37(3), 554-579.

Busaba, W. Y. (2006) Bookbuilding, the option to withdraw, and the timing of IPOs. Journal of Corporate Finance, 12, 159-186.

Busaba, W. Y., Benveniste, L. M., \& Guo, R-J. (2001). The option to withdraw IPOs 
during the premarket: Empirical analysis. Journal of Financial Economics, 60, 73-102.

Cable, D. M., \& Shane, S. (1997). A prisoner's dilemma approach to entrepreneur-venture capitalist relationships. Academy of Management Review, 22(1), 142-176.

Carter, R., \& Manaster, S. (1990). Initial public offerings and underwriter reputation. The Journal of Finance, 45, 1045-1067.

Certo, S. T., Covin, J., Daily, C. M., \& Dalton, D. (2001). Wealth and the effects of founder management among IPO-stage new ventures. Strategic Management Journal, 22 (6/7), 641-658.

Certo, S. T., Holcomb, T. R., \& Holmes, R. M. (2009). IPO research in managment and entrepreneurship: Moving the agenda forward. Journal of Management, 35, 1340-1378.

Chahine, S., Filatotchev, I., \& Wright, M. (2007). Venture capitalists, business angels, and performance of entrepreneurial IPOs in the UK and France. Journal of Business Finance \& Accounting, 34(3 \& 4), 505-528.

Chahine, S., Filatotchev, I., \& Zahra, S. (2011). Building perceived quality of founder-involved IPO firms: Founders' effects on board selection and stock market performance. Entrepreneurship Theory and Practice, 35(2), 319-335.

Chahine, S., \& Goergen, M. (2011). VC board representation and performance of US IPOs. Journal of Business Finance \& Accounting, 38(3 \& 4), 413-445.

Chancharat, N., Krishnamurti, C., \& Tian, G. G. (2012). Board structure and survival of new economy firms. Corporate Governance: An International Review, 20, 144-163.

Coles, J., Daniel, N., \& Naveen, L. (2008). Boards: Does one size fit all? Journal of Financial Economics, 87(2), 329-356.

Cosh, A., \& Hughes, A. (1987). The anatomy of corporate control: Directors, shareholders and executive remuneration in giant US and UK companies. Cambridge Journal of Economics, 11, 285-313.

Daily, C., \& Dalton, D. (1992). Financial performance of founder-managed versus professionally managed small corporations. Journal of Small Business Management, 30(2), 25-34.

Davis, J., Schoorman, F., \& Donaldson, L. (1997). Toward a stewardship theory of management. Academy of Management Review, 22(1), 20-47.

Duchin, R., Matsusaka, J., \& Ozbas, O. (2010). When are outside directors effective? Journal of Financial Economics, 96, 195-214.

Dunbar, C. G., \& Foerster, S. R. (2008). Second time lucky? Withdrawn IPOs that return to the market. Journal of Financial Economics, 87, 610-635.

Espenlaub, S., Khurshed, A., \& Mohamed, A. (2012). IPO survival in a reputational market. Journal of Business Finance \& Accounting, 39(3 \& 4), 427-463.

Fahlenbrach, R. (2009). Founder CEO, investment decisions, and stock market performance. Journal of Financial and Quantitative Analysis, 44, 439-466.

Faleye, O., Hoitash, R., \& Hoitash, U. (2011). The costs of intense board monitoring. Journal of Financial Economics, 101, 160-181.

Fama, E. F. (1980). Agency problems and the theory of the firm. Journal of Political Economy, 88, 134-145. 
Fama, E. F., \& Jensen, M. C. (1983). Separation of ownership and control. Journal of Law and Economics, 26(2), 301-325.

Farag, H., Mallin, C., \& Ow-Yong, K. (2014). Governance, ownership structure, and performance of entrepreneurial IPOs in AIM companies. Corporate Governance: An International Review, 22(2), 100-115.

Filatotchev, I. (2006). Effects of executive characteristics and venture capital involvement on board composition and share ownership in IPO firms. British Journal of Management, 17, 75-92.

Florin, J. (2005). Is venture capital worth it? Effects on firm performance and founder returns. Journal of Business Venturing,20, 113-135.

Franks, J., Mayer, C., \& Renneboog, L. (2001). Who disciplines management in poorly performing companies? Journal of Financial Intermediation, 10, 209-248.

Gómez-Mejía, L., Cruz, C., \& Imperatore, C. (2014). Financial reporting and the protection of socioemotional wealth in family-controlled firms. European Accounting Review, 23(3), 387-402.

Gao, N., \& Jain, B. (2011). Founder CEO management and the long-run investment performance of IPO firms. Journal of Banking and Finance, 35, 1669-1682.

Gao, N., \& Jain, B. (2012). Founder management and the market for corporate control for IPO firms: The moderating effect of the power structure of the firm. Journal of Business Venturing, 27, 112-126.

Gedajlovic, E., Lubatkin, M., \& Schulze, W. (2004). Crossing the threshold from founder management to professional management: A governance perspective. Journal of Management Studies, 41(5), 899-912.

Groh, A. P., Liechtenstein, H., \& Lieser, K. (2010). The European venture capital and private equity country attractiveness indices. Journal of Corporate Finance, 16, 205-224.

Guest, P. M. (2008). The determinants of board size and composition: Evidence from the UK. Journal of Corporate Finance, 14, 51-72.

Hambrick, D. C., \& Mason, P. A. (1984). Upper echelons: The organization as a reflection of its top managers. Academy of Management Review, 9(2), 193-206.

Harris, M., \& Raviv, A. (1988). Corporate governance: Voting rights and majority rules. Journal of Financial Economics, 20, 203-235.

Harris, M., \& Raviv, A. (2008). A theory of board control and size. The Review of Financial Studies, 21, 1797-1831.

He, L. (2008). Do founders matter? A study of executive compensation, governance structure and firm performance. Journal of Business Venturing, 23, 257-279.

Hellmann, T., \& Puri, M. (2002). Venture capital and the professionalization of start-up firms: Empirical evidence. The Journal of Finance, 57(1), 169-197.

Hermalin, B., \& Weisbach, M. S. (1998). Endogenously chosen boards of directors and their monitoring of the CEO. American Economic Review, 88, 96-118.

Higashide, H., \& Birley, S. (2002). The consequences of conflict between the venture capitalist and the entrepreneurial team in the United Kingdom from the perspective of the venture capitalist. Journal of Business Venturing, 17, 59-81.

Hsu, H., \& Wu, C. (2014). Board composition, grey directors and corporate failure in the UK. The British Accounting Review, 46, 215-227.

Jaggi, B., \& Leung, S. (2007). Impact of family dominance on monitoring of earnings 
management by audit committees: Evidence from Hong Kong. Journal of International Accounting, Auditing and Taxation, 16, 27-50.

Jensen, M. C. (1986). Agency costs of free cash flow, corporate finance and takeovers. American Economic Review, 76(2), 323-339.

Jensen, M. C. (1993). The modern industrial revolution, exit and the failure of internal control systems. The Journal of Finance, 48, 831-880.

Jensen, M. C., \& Meckling, W. H. (1976). Theory of the firm: Managerial behaviour, agency costs and ownership structure. Journal of Financial Economics, 13, 305-360.

Kaplan, S. N., \& Strömberg, P. (2003). Financial contracting theory meets the real world: An empirical analysis of venture capital contracts. The Review of Economic Studies, 70(2), 281-315.

Kaplan, S. N., \& Strömberg, P. (2004). Characteristics, contracts, and actions: Evidence from venture capitalist analyses. The Journal of Finance, 64(5), 2177-2210.

Kroll, M., Walters, B. A., \& Le, S. A. (2007). The impact of board composition and top management team ownership structure on post-IPO performance in young entrepreneurial firms. Academy of Management Journal, 50, 1198-1216.

La Porta, R., Lopez-de-Silanes, F., \& Shleifer, A. (1999). Corporate ownership around the world. The Journal of Finance, 54(2), 471-517.

Le, S., Kroll, M., \& Walters, B. (2013). Outside directors' experience, TMT firm-specific human capital, and firm performance in entrepreneurial IPO firms. Journal of Business Research, 66, 533-539.

Lerner, J. (1995). Venture capitalists and the oversight of private firms. The Journal of Finance, 50(1), 301-318.

Linck, J. S., Netter, J. M., \& Yang, T. (2008). The determinants of board structure. Journal of Financial Economics, 87, 308-328.

Mallin, C., Melis, A., \& Gaia, S. (2015). The remuneration of independent directors in the UK and Italy: An empirical analysis based on agency theory. International Business Review, 24, 175-186.

Migliorati, K., \& Vismara, S. (2014). Ranking Underwriters of European IPOs. European Financial Management, 20(5), 891-925.

Nelson, T. (2003). The persistence of founder influence: Management, ownership, and performance effects at initial public offering. Strategic Management Journal, 24, $707-724$.

Raheja, C. (2005). Determinants of board size and composition: A theory of corporate boards. Journal of Financial and Quantitative Analysis, 40, 283-306.

Shekhar, C., \& Stapledon, G. (2007). Governance structures of initial public offerings in Australia. Corporate Governance: An International Review, 15, 1177-1189.

Shivdasani, A., \& Yermack, D. (1999). CEO involvement in the selection of new board members: An empirical analysis. The Journal of Finance, 54, 1829-1853.

Shleifer, A., \& Vishny, R. W. (1986). Large shareholders and corporate control. Journal of Political Economy, 94(3), 461-488.

Short, H., \& Keasey, K. (1999). Managerial ownership and the performance of firms: Evidence from the UK. Journal of Corporate Finance, 5, 79-101.

Stulz, R. (1988). Managerial control of voting rights: Financing policies and the market for corporate control. Journal of Financial Economics, 20, 25-54. 
Sundaramurthy, C., \& Lewis, M. (2006). Control and collaboration: Paradoxes of governance. Academy of Management Review, 28(3), 397-415.

Tabachnick, B., \& Fidell, L. (2007). Using multivariate statistics. Pearson/Allyn \& Bacon, London.

UK Corporate Governance Code. (2014). The UK Corporate Governance Code. Financial Reporting Council, London.

Villalonga, B., \& Amit, R. (2006). How do family ownership, management, and control affect firm value? Journal of Financial Economics, 80, 385-417.

Wang, T., \& Song, M. (2016). Are founder directors detrimental to new ventures at initial public offering? Journal of Management, 42(3), 644-670.

Wasserman, N. (2006). Stewards, agents, and the founder discount: Executive compensation in new ventures. Academy of Management Journal, 49(5), 960-976.

Zacharakis, A. L., \& Meyer, G. D. (2000). The potential of actuarial decision models: Can they improve the venture capital investment decision? Journal of Business Venturing, 15(4), 323-346.

Zou, H., Chen, X., Lam, L., \& Liu, X. (2016). Psychological capital and conflict management in the entrepreneur-venture capitalist relationship in China: The entrepreneur perspective. International Small Business Journal, 34(4), 446-467. 
Table 1

Descriptive statistics and univariate analysis

\begin{tabular}{|c|c|c|c|c|c|c|c|c|c|c|c|}
\hline \multirow[b]{2}{*}{ Variables } & \multicolumn{3}{|c|}{ Overall } & \multicolumn{3}{|c|}{$\begin{array}{c}\text { Founder-managed } \\
(\mathrm{n}=96)\end{array}$} & \multicolumn{3}{|c|}{$\begin{array}{c}\text { Non-founder-managed } \\
(\mathrm{n}=114)\end{array}$} & \multirow[b]{2}{*}{ t-test } & \multirow[b]{2}{*}{$\begin{array}{c}\text { Wilcoxon } \\
\text { test }\end{array}$} \\
\hline & Mean & Median & Std dev. & Mean & Median & $\begin{array}{c}\text { Std } \\
\text { dev. }\end{array}$ & Mean & Median & $\begin{array}{l}\text { Std } \\
\text { dev. }\end{array}$ & & \\
\hline ED (\%) & |46.41 & 7.73 & 14.34 & \begin{tabular}{|l|}
51.69 \\
\end{tabular} & 50 & 14.35 & 42.81 & 42.86 & 13.37 & $\mid-4.11$ & -3.9 \\
\hline INED (\%) & 36.85 & 40 & 12.92 & 36.84 & 33.33 & 12.92 & 36.91 & 40 & 16.50 & 0.03 & 0.60 \\
\hline GREY (\%) & 16.71 & 14.29 & 17.23 & 12.47 & 0 & 15.97 & 20.28 & 16.67 & 17.51 & $3.35 * * *$ & $3.69^{* * *}$ \\
\hline INED_NED (\%) & 71.51 & 75 & 28.60 & 78.43 & 100 & 27.09 & 65.69 & 66.67 & 28.66 & $-3.29 * * *$ & $-3.51 * * *$ \\
\hline FDR_MGD & 0.46 & 0 & 0.50 & & & & & & & & \\
\hline FDR_OWN (\%) & 14.07 & 1.35 & 20.37 & 27.83 & 23.90 & 21.56 & 2.49 & 0 & 8.99 & $-11.43 * * *$ & $-11.41 * * *$ \\
\hline VC_OWN (\%) & 4.86 & 0 & 10.60 & 4.28 & 0 & 10.21 & 5.35 & 0 & 11.01 & 0.72 & 0.83 \\
\hline CEO_AGE & 47.27 & 47.00 & 8.68 & 45.24 & 45 & 9.83 & 48.97 & 49 & 7.18 & $3.17 * * *$ & $3.24 * * *$ \\
\hline LEV & 0.34 & 0.15 & 0.53 & 0.16 & 0.06 & 0.24 & 0.48 & 0.33 & 0.65 & $4.56 * * *$ & $5.14 * * *$ \\
\hline LnCOM_SIZ & 10.76 & 10.60 & 2.09 & 9.81 & 9.80 & 1.73 & 11.55 & 11.56 & 2.05 & $6.56 * * *$ & $5.86^{* * *}$ \\
\hline COM_AGE & 22.82 & 11 & 35.39 & 9.44 & 8 & 6.65 & 34.08 & 19 & 44.72 & $5.35^{* * *}$ & $5.86 * * *$ \\
\hline UNDERWRITER (\%) & 3.52 & 2.42 & 3.47 & 3.19 & 0.95 & 3.78 & 3.81 & 3.66 & 3.18 & 1.29 & $2.27 * *$ \\
\hline FCF & $\mid-0.00$ & 0.11 & 0.43 & $\mid-0.08$ & 0.1 & 0.53 & 0.07 & 0.11 & 0.30 & $2.49 * *$ & 1.57 \\
\hline
\end{tabular}

Notes: (1) ***, ** and * indicate significance at the $\mathrm{p}<0.01, \mathrm{p}<0.05$ and $\mathrm{p}<0.1$ levels, respectively, based on two-tailed tests. (2) ED: the percentage of total board members who are executive directors; INED: the percentage of total board members who are independent NEDs; GREY: the percentage of total board members who are grey directors; INED_NED: the percentage of total NEDs who are independent directors; FDR_MGD: the presence of a founder who holds the position of CEO or chairman; FDR_OWN: the percentage of the company shares owned by founders; VC_OWN: the percentage of the company shares owned by venture capitalists; CEO_AGE: the ages of CEOs; LEV: the ratio of total debts to total assets; LnCOM_SIZ: natural log of total assets; COM_AGE: company age; UNDERWRITER: underwriter reputation measured by the market share of the underwriter across the sample period; FCF: the ratio of free cash flow to total assets. 
Table 2

Correlations among variables

\begin{tabular}{llllllllllll}
1 & 2 & 3 & 4 & 5 & 6 & 7 & 8 & 9 & 10 & 11 \\
\hline
\end{tabular}

\begin{tabular}{|c|c|c|c|c|c|c|c|c|c|c|c|c|c|c|c|c|c|c|c|c|c|c|c|c|}
\hline 1 & ED & 1.00 & & & & & & & & & & & & & & & & & & & & & & \\
\hline 2 & INED & -0.31 & $* * *$ & 1.00 & & & & & & & & & & & & & & & & & & & & \\
\hline 3 & GREY & -0.57 & $* * *$ & -0.61 & $* * *$ & 1.00 & & & & & & & & & & & & & & & & & & \\
\hline 4 & INED_NED & 0.35 & $* * *$ & 0.74 & $* * *$ & -0.93 & $* * *$ & 1.00 & & & & & & & & & & & & & & & & \\
\hline 5 & FDR_MGD & 0.27 & $* * *$ & -0.00 & & -0.23 & $* * *$ & 0.22 & $* * *$ & 1.00 & & & & & & & & & & & & & & \\
\hline 6 & FDR_OWN & 0.32 & $* * *$ & 0.02 & & -0.28 & $* * *$ & 0.25 & $* * *$ & 0.62 & $* * *$ & 1.00 & & & & & & & & & & & & \\
\hline 7 & VC_OWN & -0.13 & $*$ & -0.03 & & 0.14 & $* *$ & -0.12 & * & -0.05 & & -0.17 & $* *$ & 1.00 & & & & & & & & & & \\
\hline 8 & CEO_AGE & -0.18 & $* *$ & 0.21 & $* * *$ & -0.04 & & 0.08 & & -0.21 & $* * *$ & -0.17 & $* *$ & 0.05 & & 1.00 & & & & & & & & \\
\hline 9 & LEV & -0.10 & & 0.16 & $* *$ & -0.06 & & 0.06 & & -0.30 & $* * *$ & -0.21 & $* * *$ & 0.07 & & 0.06 & & 1.00 & & & & & & \\
\hline 10 & LnCOM_SIZ & -0.41 & $* * *$ & 0.24 & $* * *$ & 0.13 & * & -0.09 & & -0.41 & $* * *$ & -0.29 & $* * *$ & -0.05 & & 0.35 & $* * *$ & 0.09 & & 1.00 & & & & \\
\hline 11 & LnCOM_AGE & -0.14 & * & 0.17 & $* *$ & -0.03 & & 0.06 & & -0.38 & $* * *$ & -0.25 & $* * *$ & -0.01 & & 0.33 & $* * *$ & 0.24 & $* * *$ & 0.42 & $* * *$ & 1.00 & & \\
\hline 12 & UNDERWRITER & -0.31 & $* * *$ & 0.15 & $* *$ & 0.13 & & -0.08 & & -0.09 & & -0.14 & * & 0.06 & & 0.09 & & 0.02 & & 0.39 & $* * *$ & 0.05 & & 1.00 \\
\hline 13 & FCF & 0.08 & & 0.14 & ** & -0.19 & $* * *$ & 0.17 & $* *$ & -0.17 & $* *$ & -0.06 & & -0.13 & * & 0.24 & $* * *$ & 0.20 & $* * *$ & 0.43 & $* * *$ & 0.38 & $* * *$ & 0.03 \\
\hline
\end{tabular}

Notes: (1) ***,** and * indicate significance at the $\mathrm{p}<0.01, \mathrm{p}<0.05$ and $\mathrm{p}<0.1$ levels, respectively. (2) ED: the percentage of total board members who are executive directors; INED: the percentage of total board members who are independent NEDs; GREY: the percentage of total board members who are grey directors; INED_NED: the percentage of total NEDs who are independent directors; FDR MGD: the presence of a founder who holds the position of CEO or chairman; FDR OWN: the percentage of the company shares owned by founders; VC OWN: the percentage of the company shares owned by venture capitalists; CEO_AGE: the ages of CEOs; LEV: the ratio of total debts to total assets; LnCOM_SIZ: natural log of total assets; LnCOM_AGE: company age; UNDERWRITER: underwriter reputation measured by the market share of the underwriter across the sample period; FCF: the ratio of free cash flow to total assets. 
Table 3

OLS analysis of the relationships between founders, venture capital ownership and the percentage of executive directors on the board

\begin{tabular}{|c|c|c|}
\hline VARIABLES & $\begin{array}{l}\text { (1) } \\
\mathrm{ED}\end{array}$ & $\begin{array}{l}(2) \\
E D\end{array}$ \\
\hline FDR_MGD & $\begin{array}{c}4.399 * * \\
(2.169)\end{array}$ & \\
\hline FDR_OWN & & $\begin{array}{c}0.130 * * * \\
(0.045)\end{array}$ \\
\hline VC_OWN & $\begin{array}{l}-0.129 \\
(0.091)\end{array}$ & $\begin{array}{l}-0.098 \\
(0.086)\end{array}$ \\
\hline CEO_AGE & $\begin{array}{l}-0.082 \\
(0.110)\end{array}$ & $\begin{array}{l}-0.075 \\
(0.108)\end{array}$ \\
\hline LEV & $\begin{array}{l}-1.601 \\
(1.672)\end{array}$ & $\begin{array}{l}-1.762 \\
(1.548)\end{array}$ \\
\hline LnCOM_SIZ & $\begin{array}{c}-2.812 * * * \\
(0.624)\end{array}$ & $\begin{array}{c}-2.892 * * * \\
(0.578)\end{array}$ \\
\hline LnCOM_AGE & $\begin{array}{c}0.338 \\
(0.925)\end{array}$ & $\begin{array}{c}0.266 \\
(0.895)\end{array}$ \\
\hline UNDERWRITER & $\begin{array}{c}-0.523^{*} \\
(0.277)\end{array}$ & $\begin{array}{c}-0.461^{*} \\
(0.268)\end{array}$ \\
\hline FCF & $\begin{array}{c}9.950 * * * \\
(3.298)\end{array}$ & $\begin{array}{c}9.783^{* * *} \\
(3.201)\end{array}$ \\
\hline Constant & $\begin{array}{c}80.713 * * * \\
(7.271)\end{array}$ & $\begin{array}{c}81.300 * * * \\
(6.546)\end{array}$ \\
\hline Observations & 210 & 210 \\
\hline Adj. R-squared & 0.270 & 0.282 \\
\hline F-value & $13.49 * * *$ & $13.99 * * *$ \\
\hline \multicolumn{3}{|c|}{$\begin{array}{l}\text { Notes: }(1) * * *, * * \text { and } * \text { indicate significance at the } \mathrm{p}<0.01, \mathrm{p}<0.05 \text { and } \mathrm{p}<0.1 \text { levels, respectively, based on } \\
\text { two-tailed tests. Robust standard errors are in parentheses. (2) ED: the percentage of total board members who are } \\
\text { executive directors; FDR_MGD: the presence of a founder who holds the position of CEO or chairman; FDR_OWN: } \\
\text { the percentage of the company shares owned by founders; VC_OWN: the percentage of the company shares owned } \\
\text { by venture capitalists; CEO_AGE: the ages of CEOs; LEV: the ratio of total debts to total assets; LnCOM_SIZ: } \\
\text { natural log of total assets; LnCOM_AGE: company age; UNDERWRITER: underwriter reputation measured by the } \\
\text { market share of the underwriter across the sample period; FCF: the ratio of free cash flow to total assets. }\end{array}$} \\
\hline
\end{tabular}


Table 4.

OLS analysis of the relationships between founders, venture capital ownership and the structure of NEDs

\begin{tabular}{|c|c|c|c|c|c|c|}
\hline VARIABLES & $\begin{array}{c}(1) \\
\text { INED }\end{array}$ & $\begin{array}{c}(2) \\
\text { GREY }\end{array}$ & $\begin{array}{c}\text { (3) } \\
\text { INED_NED }\end{array}$ & $\begin{array}{c}(4) \\
\text { INED }\end{array}$ & $\begin{array}{c}\text { (5) } \\
\text { GREY }\end{array}$ & $\begin{array}{c}\text { (6) } \\
\text { INED_NED }\end{array}$ \\
\hline FDR_MGD & $\begin{array}{c}5.807 * * \\
(2.587)\end{array}$ & $\begin{array}{c}-8.677^{* *} \\
(3.371)\end{array}$ & $\begin{array}{c}15.764^{* * * *} \\
(5.098)\end{array}$ & & & \\
\hline FDR_OWN & & & & $\begin{array}{l}0.105^{*} \\
(0.054)\end{array}$ & $\begin{array}{c}-0.219 * * * \\
(0.058)\end{array}$ & $\begin{array}{c}0.347 * * * \\
(0.104)\end{array}$ \\
\hline VC_OWN & $\begin{array}{l}-0.055 \\
(0.101)\end{array}$ & $\begin{array}{c}0.185 \\
(0.124)\end{array}$ & $\begin{array}{l}-0.271 \\
(0.192)\end{array}$ & $\begin{array}{l}-0.035 \\
(0.103)\end{array}$ & $\begin{array}{c}0.136 \\
(0.117)\end{array}$ & $\begin{array}{l}-0.198 \\
(0.183)\end{array}$ \\
\hline CEO_AGE & $\begin{array}{c}0.253 * * \\
(0.113)\end{array}$ & $\begin{array}{l}-0.157 \\
(0.143)\end{array}$ & $\begin{array}{c}0.377 \\
(0.234)\end{array}$ & $\begin{array}{c}0.254^{* *} \\
(0.121)\end{array}$ & $\begin{array}{l}-0.166 \\
(0.151)\end{array}$ & $\begin{array}{c}0.388 \\
(0.254)\end{array}$ \\
\hline LEV & $\begin{array}{c}5.154^{* * * *} \\
(1.522)\end{array}$ & $\begin{array}{l}-3.038^{*} \\
(1.789)\end{array}$ & $\begin{array}{l}4.996^{*} \\
(2.859)\end{array}$ & $\begin{array}{c}4.516^{* * * *} \\
(1.507)\end{array}$ & $\begin{array}{c}-2.480^{*} \\
(1.490)\end{array}$ & $\begin{array}{c}3.656 \\
(2.577)\end{array}$ \\
\hline LnCOM_SIZ & $\begin{array}{c}1.376 * * \\
(0.667)\end{array}$ & $\begin{array}{l}1.526^{*} \\
(0.794)\end{array}$ & $\begin{array}{l}-2.049 * \\
(1.234)\end{array}$ & $\begin{array}{l}1.109 * \\
(0.636)\end{array}$ & $\begin{array}{c}1.775 * * * \\
(0.681)\end{array}$ & $\begin{array}{c}-2.626^{* * *} \\
(1.118)\end{array}$ \\
\hline LnCOM_AGE & $\begin{array}{c}1.000 \\
(1.032)\end{array}$ & $\begin{array}{l}-1.101 \\
(0.985)\end{array}$ & $\begin{array}{c}2.455 \\
(1.883)\end{array}$ & $\begin{array}{c}0.742 \\
(1.008)\end{array}$ & $\begin{array}{l}-0.867 \\
(0.964)\end{array}$ & $\begin{array}{c}1.904 \\
(1.845)\end{array}$ \\
\hline UNDERWRITER & $\begin{array}{c}0.340 \\
(0.286)\end{array}$ & $\begin{array}{c}0.223 \\
(0.334)\end{array}$ & $\begin{array}{l}-0.114 \\
(0.544)\end{array}$ & $\begin{array}{c}0.414 \\
(0.287)\end{array}$ & $\begin{array}{c}0.106 \\
(0.316)\end{array}$ & $\begin{array}{c}0.093 \\
(0.517)\end{array}$ \\
\hline FCF & $\begin{array}{l}-0.729 \\
(2.411)\end{array}$ & $\begin{array}{c}-9.406^{* *} \\
(4.188)\end{array}$ & $\begin{array}{l}12.768^{*} \\
(6.871)\end{array}$ & $\begin{array}{l}-0.553 \\
(2.433)\end{array}$ & $\begin{array}{c}-9.301^{* *} \\
(4.082)\end{array}$ & $\begin{array}{l}12.880^{*} \\
(6.724)\end{array}$ \\
\hline Constant & $\begin{array}{c}2.339 \\
(9.539)\end{array}$ & $\begin{array}{c}13.734 \\
(11.941)\end{array}$ & $\begin{array}{c}62.522 * * * \\
(19.065)\end{array}$ & $\begin{array}{c}6.818 \\
(8.671)\end{array}$ & $\begin{array}{c}10.485 \\
(10.206)\end{array}$ & $\begin{array}{c}67.261^{* * *} \\
(18.717)\end{array}$ \\
\hline Observations & 210 & 210 & 210 & 210 & 210 & 210 \\
\hline Adj. R-squared & 0.129 & 0.124 & 0.106 & 0.119 & 0.134 & 0.103 \\
\hline F-value & $3.00^{* * *}$ & $5.59 * * *$ & $4.00 * * *$ & $2.88^{* * *}$ & $6.97 * * *$ & $4.07 * * *$ \\
\hline
\end{tabular}

Notes: (1) ${ }^{* * *},{ }^{* *}$ and $*$ indicate significance at the $\mathrm{p}<0.01, \mathrm{p}<0.05$ and $\mathrm{p}<0.1$ levels, respectively, based on two-tailed tests. Robust standard errors are in parentheses. (2) INED: the percentage of total board members who are independent NEDs; GREY: the percentage of total board members who are grey directors; INED_NED: the percentage of total NEDs who are independent directors; FDR_MGD: the presence of a founder who holds the position of CEO or chairman; FDR_OWN: the percentage of the company shares owned by founders; VC_OWN: the percentage of the company shares owned by venture capitalists; CEO_AGE: the ages of CEOs; LEV: the ratio of total debts to total assets; LnCOM_SIZ: natural log of total assets; LnCOM_AGE: company age; UNDERWRITER: underwriter reputation measured by the market share of the underwriter across the sample period; FCF: the ratio of free cash flow to total assets. 
Table 5.

OLS analysis of the effect of venture capital on board structure in founder-managed and non-founder-managed IPO firms

\begin{tabular}{|c|c|c|c|c|c|c|c|c|}
\hline \multirow[b]{3}{*}{ VARIABLES } & \multicolumn{4}{|c|}{ Founder-managed Firms } & \multicolumn{4}{|c|}{ Non-founder-managed Firms } \\
\hline & (1) & (2) & (3) & (4) & (5) & (6) & (7) & $(8)$ \\
\hline & ED & INED & GREY & INED_NED & ED & INED & GREY & INED_NED \\
\hline \multirow[t]{2}{*}{ VC_OWN } & $-0.385^{* * *}$ & -0.069 & $0.430 * *$ & $-0.564^{*}$ & 0.077 & -0.049 & -0.002 & -0.052 \\
\hline & $(0.108)$ & $(0.161)$ & $(0.211)$ & $(0.318)$ & $(0.090)$ & $(0.137)$ & $(0.137)$ & $(0.245)$ \\
\hline \multirow[t]{2}{*}{ CEO_AGE } & -0.068 & $0.249 *$ & -0.135 & 0.254 & -0.090 & $0.422 * *$ & $-0.423^{*}$ & $0.909 * *$ \\
\hline & $(0.125)$ & $(0.127)$ & $(0.143)$ & $(0.239)$ & $(0.218)$ & $(0.196)$ & $(0.235)$ & $(0.363)$ \\
\hline \multirow[t]{2}{*}{ LEV } & -1.392 & -2.457 & 6.331 & -5.137 & -2.309 & $6.113 * * *$ & $-3.902 *$ & $6.375^{*}$ \\
\hline & $(4.551)$ & (4.513) & $(6.844)$ & $(10.845)$ & (1.709) & (1.492) & $(2.062)$ & (3.334) \\
\hline \multirow{2}{*}{ LnCOM_SIZ } & $-4.050 * * *$ & 1.223 & $3.141 * * *$ & $-3.870 * *$ & $-2.314 * * *$ & 1.276 & 1.041 & -1.786 \\
\hline & $(0.954)$ & $(0.956)$ & $(1.130)$ & $(1.945)$ & $(0.807)$ & $(0.861)$ & $(0.910)$ & (1.428) \\
\hline \multirow[t]{2}{*}{ LnCOM_AGE } & -0.179 & 0.644 & 0.485 & -0.661 & 0.338 & 0.392 & -0.457 & 1.684 \\
\hline & (1.637) & $(1.695)$ & (1.969) & (3.227) & $(1.067)$ & (1.192) & (1.097) & $(2.056)$ \\
\hline \multirow[t]{2}{*}{ UNDERWRITER } & -0.534 & -0.281 & $0.910 * *$ & $-1.383^{*}$ & -0.472 & $1.102 * *$ & -0.688 & $1.571 * *$ \\
\hline & $(0.358)$ & $(0.349)$ & $(0.456)$ & $(0.733)$ & $(0.433)$ & $(0.449)$ & $(0.434)$ & $(0.742)$ \\
\hline \multirow[t]{2}{*}{ FCF } & $9.984 * * *$ & -2.747 & $-8.208^{* *}$ & $11.563^{*}$ & $15.164 * * *$ & 4.769 & $-19.659 * * *$ & $24.961^{* *}$ \\
\hline & (3.758) & (3.010) & (3.899) & (6.948) & $(4.642)$ & $(5.036)$ & (6.771) & $(9.843)$ \\
\hline \multirow[t]{2}{*}{ Constant } & $98.758 * * *$ & 13.689 & -19.657 & $114.813^{* * *}$ & $74.022 * * *$ & -6.798 & $36.063 * *$ & 26.592 \\
\hline & (8.664) & (10.235) & $(12.076)$ & $(20.380)$ & $(10.960)$ & (13.083) & $(14.662)$ & $(24.202)$ \\
\hline Observations & 96 & 96 & 96 & 96 & 114 & 114 & 114 & 114 \\
\hline Adj. R-squared & 0.341 & 0.065 & 0.233 & 0.118 & 0.124 & 0.190 & 0.160 & 0.159 \\
\hline F-value & $10.75^{* * *}$ & 0.97 & $6.74 * * *$ & $3.54 * * *$ & $4.22 * * *$ & $4.70^{* * *}$ & $4.45^{* * *}$ & $4.18^{* * *}$ \\
\hline
\end{tabular}

Notes: (1) ***,** and * indicate significance at the $\mathrm{p}<0.01, \mathrm{p}<0.05$ and $\mathrm{p}<0.1$ levels, respectively, based on two-tailed tests. Robust standard errors are in parentheses. (2) ED: the percentage of total board members who are executive directors; INED: the percentage of total board members who are independent NEDs; GREY: the percentage of total board members who are grey directors; INED_NED: the percentage of total NEDs who are independent directors; VC_OWN: the percentage of the company shares owned by venture capitalists; CEO_AGE: the age of CEOs; LEV: the ratio of total debts to total assets; LnCOM_SIZ: natural log of total assets; LnCOM_AGE: company age; UNDERWRITER: underwriter reputation measured by the market share of the underwriter across the sample period; FCF: the ratio of free cash flow to total assets. 
Table 6.

OLS analysis of the effect on board structure of the presence of founders on a nomination committee

\begin{tabular}{|c|c|c|c|c|}
\hline VARIABLES & $\begin{array}{l}(1) \\
E D\end{array}$ & $\begin{array}{c}(2) \\
\text { INED }\end{array}$ & $\begin{array}{c}(3) \\
\text { GREY }\end{array}$ & $\begin{array}{c}\text { (4) } \\
\text { INED_NED }\end{array}$ \\
\hline FDR_NC & $\begin{array}{l}5.091 * * \\
(2.331)\end{array}$ & $\begin{array}{l}4.480^{*} \\
(2.585)\end{array}$ & $\begin{array}{c}-8.797 * * \\
(3.516)\end{array}$ & $\begin{array}{c}14.344^{* * *} \\
(5.266)\end{array}$ \\
\hline VC_OWN & $\begin{array}{l}-0.127 \\
(0.092)\end{array}$ & $\begin{array}{l}-0.057 \\
(0.104)\end{array}$ & $\begin{array}{c}0.184 \\
(0.129)\end{array}$ & $\begin{array}{l}-0.273 \\
(0.199)\end{array}$ \\
\hline CEO_AGE & $\begin{array}{l}-0.062 \\
(0.108)\end{array}$ & $\begin{array}{c}0.267^{* *} \\
(0.118)\end{array}$ & $\begin{array}{l}-0.190 \\
(0.147)\end{array}$ & $\begin{array}{l}0.428^{*} \\
(0.241)\end{array}$ \\
\hline LEV & $\begin{array}{l}-1.406 \\
(1.688)\end{array}$ & $\begin{array}{c}4.887 * * * \\
(1.612)\end{array}$ & $\begin{array}{c}-3.131^{*} \\
(1.847)\end{array}$ & $\begin{array}{c}4.781 \\
(3.014)\end{array}$ \\
\hline LnCOM_SIZ & $\begin{array}{c}-2.690 * * * \\
(0.649)\end{array}$ & $\begin{array}{l}1.308^{*} \\
(0.664)\end{array}$ & $\begin{array}{l}1.412 * \\
(0.802)\end{array}$ & $\begin{array}{l}-2.010 \\
(1.231)\end{array}$ \\
\hline LnCOM_AGE & $\begin{array}{c}0.165 \\
(0.908)\end{array}$ & $\begin{array}{c}0.675 \\
(0.985)\end{array}$ & $\begin{array}{l}-0.706 \\
(0.964)\end{array}$ & $\begin{array}{l}1.666 \\
(1.828)\end{array}$ \\
\hline UNDERWRITER & $\begin{array}{c}-0.454^{*} \\
(0.273)\end{array}$ & $\begin{array}{c}0.421 \\
(0.290)\end{array}$ & $\begin{array}{c}0.092 \\
(0.327)\end{array}$ & $\begin{array}{c}0.116 \\
(0.547)\end{array}$ \\
\hline FCF & $\begin{array}{c}9.874 * * * \\
(3.282)\end{array}$ & $\begin{array}{l}-0.526 \\
(2.424)\end{array}$ & $\begin{array}{c}-9.425^{* *} \\
(4.185)\end{array}$ & $\begin{array}{l}13.023^{*} \\
(6.911)\end{array}$ \\
\hline Constant & $\begin{array}{c}78.435^{* * * *} \\
(7.886)\end{array}$ & $\begin{array}{c}3.799 \\
(9.344)\end{array}$ & $\begin{array}{c}15.746 \\
(12.213)\end{array}$ & $\begin{array}{c}62.133^{* * * *} \\
(19.094)\end{array}$ \\
\hline $\begin{array}{l}\text { Observations } \\
\text { Adj. R-squared } \\
\text { F-value }\end{array}$ & $\begin{array}{c}210 \\
0.274 \\
13.74 * * *\end{array}$ & $\begin{array}{c}210 \\
0.117 \\
2.83^{* * *}\end{array}$ & $\begin{array}{c}210 \\
0.121 \\
4.84 * * *\end{array}$ & $\begin{array}{c}210 \\
0.128 \\
3.40^{* * *}\end{array}$ \\
\hline
\end{tabular}

Notes: $(1)^{* * *},{ }^{* *}$ and $*$ indicate significance at the $\mathrm{p}<0.01, \mathrm{p}<0.05$ and $\mathrm{p}<0.1$ levels, respectively, based on two-tailed tests. Robust standard errors are in parentheses. (2) ED: the percentage of total board members who are executive directors; INED: the percentage of total board members who are independent NEDs; GREY: the percentage of total board members who are grey directors; INED_NED: the percentage of total NEDs who are independent directors; FDR_NC: the presence of a founder on nomination committee; VC_OWN: the percentage of the company shares owned by venture capitalists; CEO_AGE: the ages of CEOs; LEV: the ratio of total debts to total assets; LnCOM_SIZ: natural log of total assets; LnCOM_AGE: company age; UNDERWRITER: underwriter reputation measured by the market share of the underwriter across the sample period; FCF: the ratio of free cash flow to total assets. 
Table 7.

OLS regression of the effect of institutional ownership and business angel ownership on board structure

\begin{tabular}{|c|c|c|c|c|c|c|c|c|}
\hline VARIABLES & $\begin{array}{l}(1) \\
\text { ED } \\
\end{array}$ & $\begin{array}{c}(2) \\
\text { INED }\end{array}$ & $\begin{array}{c}(3) \\
\text { GREY }\end{array}$ & $\begin{array}{c}\text { (4) } \\
\text { INED_NED }\end{array}$ & $\begin{array}{l}(5) \\
\text { ED } \\
\end{array}$ & $\begin{array}{c}(6) \\
\text { INED }\end{array}$ & $\begin{array}{c}(7) \\
\text { GREY }\end{array}$ & $\begin{array}{c}\text { (8) } \\
\text { INED_NED }\end{array}$ \\
\hline FDR_MGD & $\begin{array}{c}4.568 * * \\
(2.173)\end{array}$ & $\begin{array}{c}5.974 * * \\
(2.558)\end{array}$ & $\begin{array}{c}-9.038 * * * \\
(3.324)\end{array}$ & $\begin{array}{c}16.323^{* * *} \\
(5.015)\end{array}$ & $\begin{array}{c}4.561^{* *} \\
(2.146)\end{array}$ & $\begin{array}{c}5.911 * * \\
(2.551)\end{array}$ & $\begin{array}{c}-8.943 * * * \\
(3.284)\end{array}$ & $\begin{array}{c}16.151^{* * *} \\
(4.991)\end{array}$ \\
\hline INS_OWN & $\begin{array}{c}0.004 \\
(0.040)\end{array}$ & $\begin{array}{c}0.035 \\
(0.038)\end{array}$ & $\begin{array}{l}-0.048 \\
(0.048)\end{array}$ & $\begin{array}{c}0.080 \\
(0.075)\end{array}$ & & & & \\
\hline ANGEL_OWN & & & & & $\begin{array}{c}0.009 \\
(0.153)\end{array}$ & $\begin{array}{c}0.136 \\
(0.114)\end{array}$ & $\begin{array}{l}-0.143 \\
(0.142)\end{array}$ & $\begin{array}{c}0.199 \\
(0.237)\end{array}$ \\
\hline CEO_AGE & $\begin{array}{l}-0.095 \\
(0.107)\end{array}$ & $\begin{array}{c}0.254^{* *} \\
(0.114)\end{array}$ & $\begin{array}{l}-0.146 \\
(0.141)\end{array}$ & $\begin{array}{c}0.363 \\
(0.237)\end{array}$ & $\begin{array}{l}-0.097 \\
(0.107)\end{array}$ & $\begin{array}{c}0.242 * * \\
(0.107)\end{array}$ & $\begin{array}{l}-0.132 \\
(0.137)\end{array}$ & $\begin{array}{c}0.340 \\
(0.224)\end{array}$ \\
\hline LEV & $\begin{array}{l}-1.798 \\
(1.619)\end{array}$ & $\begin{array}{c}5.218 * * * \\
(1.561)\end{array}$ & $\begin{array}{l}-2.943 \\
(1.785)\end{array}$ & $\begin{array}{l}4.902 * \\
(2.835)\end{array}$ & $\begin{array}{l}-1.794 \\
(1.635)\end{array}$ & $\begin{array}{c}5.347 * * * \\
(1.565)\end{array}$ & $\begin{array}{c}-3.032 * \\
(1.789)\end{array}$ & $\begin{array}{l}4.964 * \\
(2.834)\end{array}$ \\
\hline LnCOM_SIZ & $\begin{array}{c}-2.758 * * * \\
(0.623)\end{array}$ & $\begin{array}{l}1.380 * * \\
(0.664)\end{array}$ & $\begin{array}{l}1.472 * \\
(0.788)\end{array}$ & $\begin{array}{l}-1.976 \\
(1.234)\end{array}$ & $\begin{array}{c}-2.749 * * * \\
(0.636)\end{array}$ & $\begin{array}{l}1.498 * * \\
(0.664)\end{array}$ & $\begin{array}{l}1.342^{*} \\
(0.810)\end{array}$ & $\begin{array}{l}-1.786 \\
(1.237)\end{array}$ \\
\hline LnCOM_AGE & $\begin{array}{c}0.337 \\
(0.905)\end{array}$ & $\begin{array}{c}0.999 \\
(1.030)\end{array}$ & $\begin{array}{l}-1.100 \\
(0.979)\end{array}$ & $\begin{array}{c}2.452 \\
(1.873)\end{array}$ & $\begin{array}{c}0.330 \\
(0.920)\end{array}$ & $\begin{array}{c}0.889 \\
(1.046)\end{array}$ & $\begin{array}{l}-0.984 \\
(0.991)\end{array}$ & $\begin{array}{c}2.291 \\
(1.882)\end{array}$ \\
\hline UNDERWRITER & $\begin{array}{c}-0.554^{*} \\
(0.287)\end{array}$ & $\begin{array}{c}0.340 \\
(0.285)\end{array}$ & $\begin{array}{c}0.250 \\
(0.347)\end{array}$ & $\begin{array}{l}-0.150 \\
(0.559)\end{array}$ & $\begin{array}{c}-0.556^{*} \\
(0.286)\end{array}$ & $\begin{array}{c}0.325 \\
(0.284)\end{array}$ & $\begin{array}{c}0.271 \\
(0.345)\end{array}$ & $\begin{array}{l}-0.184 \\
(0.558)\end{array}$ \\
\hline FCF & $\begin{array}{c}10.414 * * * \\
(3.317)\end{array}$ & $\begin{array}{l}-0.376 \\
(2.425)\end{array}$ & $\begin{array}{c}-10.268 * * \\
(4.054)\end{array}$ & $\begin{array}{c}14.080^{* *} \\
(6.651)\end{array}$ & $\begin{array}{c}10.399 * * * \\
(3.355)\end{array}$ & $\begin{array}{l}-0.522 \\
(2.441)\end{array}$ & $\begin{array}{c}-10.064^{* *} \\
(4.228)\end{array}$ & $\begin{array}{l}13.732 * \\
(6.968)\end{array}$ \\
\hline Constant & $\begin{array}{c}80.138 * * * \\
(7.474)\end{array}$ & $\begin{array}{c}1.004 \\
(9.690)\end{array}$ & $\begin{array}{c}15.936 \\
(12.348)\end{array}$ & $\begin{array}{c}58.958 * * * \\
(19.575)\end{array}$ & $\begin{array}{c}0.009 \\
(0.153)\end{array}$ & $\begin{array}{c}0.136 \\
(0.114)\end{array}$ & $\begin{array}{l}-0.143 \\
(0.142)\end{array}$ & $\begin{array}{c}0.199 \\
(0.237)\end{array}$ \\
\hline $\begin{array}{l}\text { Observations } \\
\text { Adj. R-squared } \\
\text { F-value }\end{array}$ & $\begin{array}{c}210 \\
0.261 \\
12.90 * * * \\
\end{array}$ & $\begin{array}{c}210 \\
0.130 \\
2.87 * * * \\
\end{array}$ & $\begin{array}{c}210 \\
0.115 \\
4.77 * * * \\
\end{array}$ & $\begin{array}{c}210 \\
0.101 \\
3.74 * * * \\
\end{array}$ & $\begin{array}{c}210 \\
0.261 \\
13.03^{* * *} \\
\end{array}$ & $\begin{array}{c}210 \\
0.131 \\
2.99 * * * \\
\end{array}$ & $\begin{array}{c}210 \\
0.114 \\
4.83^{* * *} \\
\end{array}$ & $\begin{array}{c}210 \\
0.100 \\
3.66^{* * *} \\
\end{array}$ \\
\hline
\end{tabular}

Notes: $(1) * * *, * *$ and $*$ indicate significance at the $\mathrm{p}<0.01, \mathrm{p}<0.05$ and $\mathrm{p}<0.1$ levels, respectively, based on two-tailed tests. Robust standard errors are in parentheses. (2) ED: the percentage of total board members who are executive directors; INED: the percentage of total board members who are independent NEDs; GREY: the percentage of total board members who are grey directors; INED_NED: the percentage of total NEDs who are independent directors; FDR_MGD: the presence of a founder who holds the position of CEO or chairman; INS_OWN: the percentage of the company shares owned by institutional shareholders; ANGEL_OWN: the percentage of the company shares owned by business angels; CEO_AGE: the age of CEOs; LEV: the ratio of total debts to total assets; LnCOM_SIZ: natural log of total assets; LnCOM_AGE: company age; UNDERWRITER: underwriter reputation measured by the market share of the underwriter across the sample period; FCF: the ratio of free cash flow to total assets. 
Table 8.

OLS regression of the effect of institutional ownership and business angel ownership on board structure in founder-managed and non-founder-managed IPO firms

\begin{tabular}{|c|c|c|c|c|c|c|c|c|}
\hline \multicolumn{9}{|c|}{ Panel A: Founder-managed firms } \\
\hline & (1) & (2) & (3) & (4) & (5) & (6) & (7) & (8) \\
\hline VARIABLES & ED & INED & GREY & INED_NED & ED & INED & GREY & INED_NED \\
\hline INS_OWN & $\begin{array}{c}-0.152 * * \\
(0.064)\end{array}$ & $\begin{array}{l}-0.075 \\
(0.060)\end{array}$ & $\begin{array}{c}0.219 * * * \\
(0.075)\end{array}$ & $\begin{array}{c}-0.315^{* *} \\
(0.123)\end{array}$ & & & & \\
\hline ANGEL_OWN & & & & & $\begin{array}{l}-0.210 \\
(0.148)\end{array}$ & $\begin{array}{c}0.183 \\
(0.163)\end{array}$ & $\begin{array}{c}0.045 \\
(0.137)\end{array}$ & $\begin{array}{l}-0.083 \\
(0.275)\end{array}$ \\
\hline CEO_AGE & $\begin{array}{l}-0.085 \\
(0.120)\end{array}$ & $\begin{array}{c}0.249 * * \\
(0.125)\end{array}$ & $\begin{array}{l}-0.119 \\
(0.134)\end{array}$ & $\begin{array}{c}0.236 \\
(0.225)\end{array}$ & $\begin{array}{l}-0.111 \\
(0.126)\end{array}$ & $\begin{array}{c}0.257 * * \\
(0.119)\end{array}$ & $\begin{array}{l}-0.101 \\
(0.147)\end{array}$ & $\begin{array}{c}0.208 \\
(0.244)\end{array}$ \\
\hline LEV & $\begin{array}{c}2.192 \\
(4.487)\end{array}$ & $\begin{array}{l}-0.996 \\
(4.631)\end{array}$ & $\begin{array}{c}1.477 \\
(7.241)\end{array}$ & $\begin{array}{c}1.712 \\
(11.149)\end{array}$ & $\begin{array}{l}-0.605 \\
(4.805)\end{array}$ & $\begin{array}{l}-2.111 \\
(4.528)\end{array}$ & $\begin{array}{c}5.276 \\
(7.343)\end{array}$ & $\begin{array}{c}-3.775 \\
(11.433)\end{array}$ \\
\hline LnCOM_SIZ & $\begin{array}{c}-3.189 * * * \\
(0.962)\end{array}$ & $\begin{array}{c}1.578 \\
(0.952)\end{array}$ & $\begin{array}{l}1.970 * \\
(1.021)\end{array}$ & $\begin{array}{l}-2.217 \\
(1.766)\end{array}$ & $\begin{array}{c}-4.051 * * * \\
(1.012)\end{array}$ & $\begin{array}{c}1.458 \\
(0.942)\end{array}$ & $\begin{array}{l}2.940 * * \\
(1.208)\end{array}$ & $\begin{array}{c}-3.633^{*} \\
(2.035)\end{array}$ \\
\hline LnCOM_AGE & $\begin{array}{l}-1.208 \\
(1.703)\end{array}$ & $\begin{array}{c}0.262 \\
(1.675)\end{array}$ & $\begin{array}{c}1.839 \\
(1.926)\end{array}$ & $\begin{array}{l}-2.554 \\
(3.122)\end{array}$ & $\begin{array}{l}-0.582 \\
(1.623)\end{array}$ & $\begin{array}{c}0.574 \\
(1.645)\end{array}$ & $\begin{array}{c}0.933 \\
(1.943)\end{array}$ & $\begin{array}{l}-1.249 \\
(3.168)\end{array}$ \\
\hline UNDERWRITER & $\begin{array}{l}-0.489 \\
(0.369)\end{array}$ & $\begin{array}{l}-0.221 \\
(0.354)\end{array}$ & $\begin{array}{l}0.807^{*} \\
(0.468)\end{array}$ & $\begin{array}{l}-1.216 \\
(0.745)\end{array}$ & $\begin{array}{l}-0.659 \\
(0.407)\end{array}$ & $\begin{array}{l}-0.297 \\
(0.346)\end{array}$ & $\begin{array}{l}1.045^{* *} \\
(0.521)\end{array}$ & $\begin{array}{c}-1.561^{*} \\
(0.815)\end{array}$ \\
\hline FCF & $\begin{array}{c}10.169 * * * \\
(3.693)\end{array}$ & $\begin{array}{l}-2.931 \\
(2.995)\end{array}$ & $\begin{array}{c}-8.190 * * \\
(3.562)\end{array}$ & $\begin{array}{l}11.414^{*} \\
(6.515)\end{array}$ & $\begin{array}{c}10.858 * * * \\
(3.980)\end{array}$ & $\begin{array}{l}-2.595 \\
(2.999)\end{array}$ & $\begin{array}{c}-9.181^{* *} \\
(3.925)\end{array}$ & $\begin{array}{l}12.841^{*} \\
(7.068)\end{array}$ \\
\hline Constant & $\begin{array}{c}94.765 * * * \\
(8.866)\end{array}$ & $\begin{array}{c}12.190 \\
(10.057)\end{array}$ & $\begin{array}{l}-14.383 \\
(11.921)\end{array}$ & $\begin{array}{c}107.434 * * * \\
(19.734)\end{array}$ & $\begin{array}{c}100.918 * * * \\
(9.993)\end{array}$ & $\begin{array}{c}10.220 \\
(10.343)\end{array}$ & $\begin{array}{l}-18.759 \\
(13.838)\end{array}$ & $\begin{array}{c}114.068 * * * \\
(22.026)\end{array}$ \\
\hline Observations & 96 & 96 & 96 & 96 & 96 & 96 & 96 & 96 \\
\hline Adj. R-squared & 0.318 & 0.078 & 0.251 & 0.140 & 0.267 & 0.071 & 0.155 & 0.071 \\
\hline F-value & $9.28 * * *$ & 1.23 & $8.22 * * *$ & $3.82 * * *$ & $8.24 * * *$ & 1.23 & $7.23 * * *$ & $3.77 * * *$ \\
\hline \multicolumn{9}{|c|}{ Panel B: Non-founder-managed firms } \\
\hline VARIABLES & $\begin{array}{l}(1) \\
E D\end{array}$ & $\begin{array}{c}(2) \\
\text { INED }\end{array}$ & $\begin{array}{c}\text { (3) } \\
\text { GREY }\end{array}$ & $\begin{array}{c}\text { (4) } \\
\text { INED_NED }\end{array}$ & $\begin{array}{l}5) \\
\text { ED } \\
\end{array}$ & $\begin{array}{c}(6) \\
\text { INED }\end{array}$ & $\begin{array}{c}(7) \\
\text { GREY }\end{array}$ & $\begin{array}{c}\text { (8) } \\
\text { INED_NED }\end{array}$ \\
\hline INS_OWN & $\begin{array}{l}-0.041 \\
(0.067)\end{array}$ & $\begin{array}{l}-0.059 \\
(0.067)\end{array}$ & $\begin{array}{c}0.083 \\
(0.087)\end{array}$ & $\begin{array}{l}-0.180 \\
(0.118)\end{array}$ & & & & \\
\hline ANGEL_OWN & & & & & $\begin{array}{c}0.041 \\
(0.220)\end{array}$ & $\begin{array}{c}0.006 \\
(0.144)\end{array}$ & $\begin{array}{l}-0.047 \\
(0.194)\end{array}$ & $\begin{array}{c}0.039 \\
(0.310)\end{array}$ \\
\hline CEO_AGE & -0.079 & $0.401 * *$ & $-0.409 *$ & $0.867 * *$ & 0.002 & $0.409 * *$ & $-0.412^{*}$ & $0.887 * *$ \\
\hline
\end{tabular}

45 


\begin{tabular}{lcccccccc} 
& $(0.212)$ & $(0.201)$ & $(0.233)$ & $(0.373)$ & $(0.217)$ & $(0.196)$ & $(0.238)$ & $(0.368)$ \\
LEV & -2.202 & $5.771^{* * *}$ & $-3.640^{*}$ & $5.631^{*}$ & -1.970 & $5.971^{* * *}$ & $-4.002^{*}$ & $6.293^{*}$ \\
& $(1.740)$ & $(1.602)$ & $(2.126)$ & $(3.282)$ & $(1.749)$ & $(1.605)$ & $(2.168)$ & $(3.420)$ \\
LnCOM_SIZ & $-2.236^{* * *}$ & $1.440^{*}$ & 0.831 & -1.313 & $-2.305^{* * *}$ & 1.296 & 1.009 & -1.742 \\
& $(0.765)$ & $(0.830)$ & $(0.839)$ & $(1.352)$ & $(0.810)$ & $(0.861)$ & $(0.910)$ & $(1.402)$ \\
LnCOM_AGE & 0.090 & 0.102 & -0.019 & 0.754 & 0.018 & 0.408 & -0.426 & 1.679 \\
& $(1.106)$ & $(1.239)$ & $(1.131)$ & $(2.087)$ & $(1.087)$ & $(1.205)$ & $(1.097)$ & $(2.040)$ \\
UNDERWRITER & -0.479 & $1.041^{* *}$ & -0.625 & $1.415^{*}$ & -0.399 & $1.085^{* *}$ & -0.686 & $1.551^{* *}$ \\
& $(0.423)$ & $(0.443)$ & $(0.431)$ & $(0.714)$ & $(0.418)$ & $(0.446)$ & $(0.431)$ & $(0.737)$ \\
FCF & $13.993^{* * *}$ & 4.422 & $-18.574^{* * *}$ & $23.067 * *$ & $14.362^{* * *}$ & 5.164 & $-19.526^{* * *}$ & $25.295^{* *}$ \\
& $(4.864)$ & $(5.026)$ & $(7.013)$ & $(9.763)$ & $(4.483)$ & $(5.000)$ & $(6.475)$ & $(9.682)$ \\
Constant & $75.122^{* * *}$ & -4.714 & $33.340^{* *}$ & 32.690 & $70.679^{* * *}$ & -6.626 & $35.948^{* *}$ & 26.861 \\
& $(11.382)$ & $(13.677)$ & $(15.151)$ & $(24.735)$ & $(11.328)$ & $(13.179)$ & $(14.718)$ & $(24.322)$ \\
& & & & & & 114 & 114 & 114 \\
Observations & 114 & 114 & 114 & 114 & 0.114 & 114 \\
Adj. R-squared & 0.124 & 0.195 & 0.170 & 0.177 & 0.119 & 0.189 & 0.160 & 0.159 \\
F-value & $4.41^{* * *}$ & $4.49^{* * *}$ & $6.98^{* * *}$ & $5.56^{* * *}$ & $3.99^{* * *}$ & $4.28^{* * *}$ & $4.30^{* * *}$ & $4.13^{* * *}$ \\
\hline
\end{tabular}

Notes: $(1)^{* * *}, * *$ and * indicate significance at the $\mathrm{p}<0.01, \mathrm{p}<0.05$ and $\mathrm{p}<0.1$ levels, respectively, based on two-tailed tests. Robust standard errors are in parentheses. (2) ED: the percentage of total board members who are executive directors; INED: the percentage of total board members who are independent NEDs; GREY: the percentage of total board members who are grey directors; INED_NED: the percentage of total NEDs who are independent directors; INS_OWN: the percentage of the company shares owned by institutional shareholders; ANGEL_OWN: the percentage of the company shares owned by business angels; CEO_AGE: the age of CEOs; LEV: the ratio of total debts to total assets; LnCOM_SIZ: natural log of total assets; LnCOM_AGE: company age; UNDERWRITER: underwriter reputation measured by the market share of the underwriter across the sample period; FCF: the ratio of free cash flow to total assets. 
Table 9.

OLS regression of the relationships between founders, venture capital and alternative proxies for board structure

\begin{tabular}{|c|c|c|c|c|c|c|c|c|}
\hline & $\begin{array}{c}\text { Full } \\
\text { Sample }\end{array}$ & $\begin{array}{c}\text { Full } \\
\text { Sample }\end{array}$ & $\begin{array}{c}\text { Founder- } \\
\text { managed } \\
\text { Firms } \\
\end{array}$ & $\begin{array}{c}\text { Non-founder- } \\
\text { managed Firms }\end{array}$ & $\begin{array}{c}\text { Full } \\
\text { Sample }\end{array}$ & $\begin{array}{c}\text { Full } \\
\text { Sample }\end{array}$ & $\begin{array}{c}\text { Founder } \\
\text { Managed Firms }\end{array}$ & $\begin{array}{l}\text { Non-founder- } \\
\text { managed Firms }\end{array}$ \\
\hline VARIABLES & $\begin{array}{c}\text { (1) } \\
\text { NED_COMS }\end{array}$ & $\begin{array}{c}(2) \\
\text { NED_COMS }\end{array}$ & $\begin{array}{c}\text { (3) } \\
\text { NED_COMS }\end{array}$ & $\begin{array}{c}(4) \\
\text { NED_COMS }\end{array}$ & $\begin{array}{c}\text { (5) } \\
\text { GREY_NVC }\end{array}$ & $\begin{array}{c}\text { (6) } \\
\text { GREY_NVC }\end{array}$ & $\begin{array}{c}\text { (7) } \\
\text { GREY_NVC }\end{array}$ & $\begin{array}{c}\text { (8) } \\
\text { GREY_NVC }\end{array}$ \\
\hline FDR_MGD & $\begin{array}{c}-4.114^{* *} \\
(2.029)\end{array}$ & & & & $\begin{array}{c}-8.737 * * * \\
(3.352)\end{array}$ & & & \\
\hline FDR_OWN & & $\begin{array}{c}-0.107^{* *} \\
(0.045)\end{array}$ & & & & $\begin{array}{c}-0.211 * * * \\
(0.058)\end{array}$ & & \\
\hline VC_OWN & $\begin{array}{c}0.142 \\
(0.110)\end{array}$ & $\begin{array}{c}0.118 \\
(0.107)\end{array}$ & $\begin{array}{c}0.407 * * * \\
(0.143)\end{array}$ & $\begin{array}{l}-0.024 \\
(0.143)\end{array}$ & $\begin{array}{c}0.081 \\
(0.115)\end{array}$ & $\begin{array}{c}0.034 \\
(0.105)\end{array}$ & $\begin{array}{c}0.382 * * \\
(0.180)\end{array}$ & $\begin{array}{l}-0.146 \\
(0.111)\end{array}$ \\
\hline CEO_AGE & $\begin{array}{c}0.032 \\
(0.135)\end{array}$ & $\begin{array}{c}0.027 \\
(0.146)\end{array}$ & $\begin{array}{c}0.090 \\
(0.180)\end{array}$ & $\begin{array}{l}-0.095 \\
(0.155)\end{array}$ & $\begin{array}{l}-0.139 \\
(0.139)\end{array}$ & $\begin{array}{l}-0.147 \\
(0.147)\end{array}$ & $\begin{array}{l}-0.082 \\
(0.136)\end{array}$ & $\begin{array}{c}-0.456^{*} \\
(0.232)\end{array}$ \\
\hline LEV & $\begin{array}{l}-1.254 \\
(1.338)\end{array}$ & $\begin{array}{l}-1.008 \\
(1.341)\end{array}$ & $\begin{array}{l}-3.444 \\
(5.383)\end{array}$ & $\begin{array}{l}-1.699 \\
(1.780)\end{array}$ & $\begin{array}{c}-3.097 * \\
(1.775)\end{array}$ & $\begin{array}{c}-2.475^{*} \\
(1.475)\end{array}$ & $\begin{array}{c}7.446 \\
(6.890)\end{array}$ & $\begin{array}{c}-3.973 * \\
(2.035)\end{array}$ \\
\hline LnCOM_SIZ & $\begin{array}{c}1.519 * * * \\
(0.506)\end{array}$ & $\begin{array}{c}1.631^{* * *} \\
(0.481)\end{array}$ & $\begin{array}{l}1.760 * * \\
(0.822)\end{array}$ & $\begin{array}{l}1.655 * * \\
(0.666)\end{array}$ & $\begin{array}{l}1.462 * \\
(0.789)\end{array}$ & $\begin{array}{l}1.736 * * \\
(0.676)\end{array}$ & $\begin{array}{c}3.062^{* * *} \\
(1.137)\end{array}$ & $\begin{array}{c}0.937 \\
(0.896)\end{array}$ \\
\hline LnCOM_AGE & $\begin{array}{l}-0.931 \\
(0.900)\end{array}$ & $\begin{array}{l}-0.827 \\
(0.896)\end{array}$ & $\begin{array}{l}-0.773 \\
(1.474)\end{array}$ & $\begin{array}{l}-1.172 \\
(1.059)\end{array}$ & $\begin{array}{l}-1.100 \\
(0.959)\end{array}$ & $\begin{array}{l}-0.841 \\
(0.935)\end{array}$ & $\begin{array}{c}0.248 \\
(1.980)\end{array}$ & $\begin{array}{l}-0.312 \\
(1.044)\end{array}$ \\
\hline UNDERWRITER & $\begin{array}{c}0.352 \\
(0.245)\end{array}$ & $\begin{array}{c}0.296 \\
(0.246)\end{array}$ & $\begin{array}{l}0.561 * \\
(0.314)\end{array}$ & $\begin{array}{l}-0.137 \\
(0.390)\end{array}$ & $\begin{array}{c}0.171 \\
(0.343)\end{array}$ & $\begin{array}{c}0.054 \\
(0.333)\end{array}$ & $\begin{array}{c}0.699 \\
(0.496)\end{array}$ & $\begin{array}{l}-0.550 \\
(0.436)\end{array}$ \\
\hline FCF & $\begin{array}{c}1.292 \\
(2.568)\end{array}$ & $\begin{array}{c}1.359 \\
(2.714)\end{array}$ & $\begin{array}{l}-0.977 \\
(2.777)\end{array}$ & $\begin{array}{c}8.385 \\
(6.518)\end{array}$ & $\begin{array}{c}-10.150 * * \\
(4.311)\end{array}$ & $\begin{array}{c}-10.100^{* *} \\
(4.214)\end{array}$ & $\begin{array}{c}-8.536^{* *} \\
(3.923)\end{array}$ & $\begin{array}{c}-21.678 * * * \\
(6.490)\end{array}$ \\
\hline Constant & $\begin{array}{c}22.857 * * * \\
(7.816)\end{array}$ & $\begin{array}{c}21.472 * * \\
(8.322)\end{array}$ & $\begin{array}{c}11.810 \\
(10.578)\end{array}$ & $\begin{array}{c}30.683 * * * \\
(9.675)\end{array}$ & $\begin{array}{c}0.081 \\
(0.115)\end{array}$ & $\begin{array}{c}0.034 \\
(0.105)\end{array}$ & $\begin{array}{c}0.382 * * \\
(0.180)\end{array}$ & $\begin{array}{l}-0.146 \\
(0.111)\end{array}$ \\
\hline $\begin{array}{l}\text { Observations } \\
\text { Adj. R-squared } \\
\text { F-value }\end{array}$ & $\begin{array}{c}210 \\
0.113 \\
4.73^{* * *}\end{array}$ & $\begin{array}{c}210 \\
0.119 \\
4.95 * * *\end{array}$ & $\begin{array}{c}96 \\
0.158 \\
4.57^{* * *}\end{array}$ & $\begin{array}{c}114 \\
0.055 \\
1.69\end{array}$ & $\begin{array}{c}210 \\
0.119 \\
5.17^{* * *}\end{array}$ & $\begin{array}{c}210 \\
0.125 \\
6.30 * * *\end{array}$ & $\begin{array}{c}96 \\
0.204 \\
5.00 * * *\end{array}$ & $\begin{array}{c}114 \\
0.199 \\
5.09 * * *\end{array}$ \\
\hline
\end{tabular}

Notes: $(1) * * *, * *$ and $*$ indicate significance at the $\mathrm{p}<0.01, \mathrm{p}<0.05$ and $\mathrm{p}<0.1$ levels, respectively, based on two-tailed tests. Robust standard errors are in parentheses. (2) NED_COMS: the percentage of NEDs who hold membership on more than one sub-committees on board; GREY_NVC: the percentage of grey directors who are not representatives of venture capitalists on board; FDR_MGD: the presence of a founder who holds the position of CEO or chairman; FDR_OWN: the percentage of the company shares owned by founders; VC_OWN: the percentage of the company shares owned by venture capitalists; CEO_AGE: the ages of CEOs; LEV: the ratio of total debts to total assets; LnCOM_SIZ: natural log of total assets; LnCOM_AGE: company age; UNDERWRITER: underwriter reputation measured by the market share of the underwriter across the sample period; FCF: the ratio of free cash flow to total assets. 